\title{
Quantitative Regionalization of W. Mujib-Wala Sub-Watersheds (Southern Jordan) Using GIS and Multivariate Statistical Techniques
}

\author{
Yahya Farhan*, Nisrin Al-Shaikh \\ Department of Geography, University of Jordan, Amman, Jordan \\ Email: *wjetfan47962@gmail.com
}

How to cite this paper: Farhan, Y. and Al-Shaikh, N. (2017) Quantitative Regionalization of W. Mujib-Wala Sub-Watersheds (Southern Jordan) Using GIS and Multivariate Statistical Techniques. Open Journal of Modern Hydrology, 7, 165-199. https://doi.org/10.4236/ojmh.2017.72010

Received: March 8, 2017

Accepted: April 25, 2017

Published: April 28, 2017

Copyright ( 92017 by authors and Scientific Research Publishing Inc. This work is licensed under the Creative Commons Attribution International License (CC BY 4.0).

http://creativecommons.org/licenses/by/4.0/ (c) (i) Open Access

\begin{abstract}
In arid and semi-arid watersheds, sustainable management of natural resources (i.e. land, water and ecological resources), and watershed management are crucial issues in applied morphometric studies. Geomorphometric parameters and their interrelationships are of paramount importance in characterizing the morphology, topography, geology and structure, hydrological potential, and geomorphic evolution of such catchments. An analysis of spatial characteristics and morphological development of the demarcated 76 subwatersheds related to W. Mujib-Wala catchment, was carried out using ASTER DEM and GIS. Multivariate statistical techniques such as Principal Component Analysis (PCA), Cluster Analysis (CA), and Discriminant Analysis (DA), were also employed to assess different aspects of drainage networks, and their morphometric properties. Principal Component Analysis (PCA) reduces the 22 morphometric parameters to five components, which explain $90.4 \%$ of total variance. The relationship of these components to the morphometric variables and to the individual sub-watersheds was evaluated, and then the degree of inter-correlation among the morphometric descriptors was explored. The 76 sub-watersheds were classified according to their individual relation to the components, and similarities in their morphometric characteristics. Regionalization of sub-watertsheds was achieved using hierarchical Cluster Analysis (CA). The validity of the resultant cluster groups was tested statistically by means of Discriminant Analysis. The present investigation provides information which highlights the benefit of geomorphometric analysis and multivariate statistics in modeling hydrological responses: i.e., surface runoff and sediment yield, hydrological assessment, water resources planning, and watershed management. Furthermore, the results can be useful for soil and water conservation planning, and assessment of flash floods potential.
\end{abstract}




\section{Keywords}

ASTER DEM, Morphometric Assessment, Principal Component

Analysis (PCA), Cluster Analysis (CA), Discriminant Analysis (DA), GIS

\section{Introduction}

The Wadi Mujib-Wala watershed is located in southern Jordan, and covers an area of $6571.4 \mathrm{~km}^{2}$. The watershed comprises two major tributaries: the northern tributary, termed Wadi Wala $\left(2063.6 \mathrm{~km}^{2}\right)$, and the southern tributary, known as Wadi Mujib $\left(4507.8 \mathrm{~km}^{2}\right)$. Both tributaries are merge $3 \mathrm{~km}$ before the Wadi discharges into the Dead Sea. Five dams have been constructed across the catchment. The most important are: the W. Mujib dam with a capacity of $16.8 \mathrm{MCM}$ per year, and the W. Wala dam with a yield of 10 MCM per year. The W. Mujib dam supplies water for the southern Ghor irrigation scheme, the Arab Potash Company, the Dead Sea chemical complex, and for development of the eastern shore of the Dead Sea. By contrast, the W. Wala dam provides ground-water recharge, while making water available to the springs and pumping wells in the lower catchment of the Wadi [1].

Quantitative analysis of drainage basis was conducted following the Second World War. Until the 1980's, morphometric analysis was carried out manually using large scale topographic maps (i.e., 1:50,000) and fieldwork [2]-[8]. However, the development of the Geographic Information System (GIS) permits digital rapid extraction and calculation of morphometric parameters from digital elevation models (DEMs) and GIS software. Thus, characterizations of land form and quantitative studies of drainage networks were carried out in different regions worldwide. Geomorphic analysis was also performed using specific geomorphic indices such as the hypsometric integral for a large number of drainage basins (or sub-watersheds) and linked hypsometric integral (HI) values to lithological resistance and tectonic uplift [9]-[19]. Since the 1970's, multivariate statistical analytical techniques applied to drainage basins morphometry of a different order have been implemented in geomorphic research [20]-[31]. Furthermore, methodology concern with applied morphometric research was elaborated and employed in watershed resources management and floods risk assessment [31]-[44], considering that watershed characteristics provide the basis for quantitative assessment of morphometric properties of watersheds as developed by Horton [2], and elaborated by Strahler [3] [4] [5]. However, a wide range of morphometric parameters (nearly 85 variables) can be extracted from drainage basins [45]. It is somewhat difficult to demonstrate which are the most effective parameters for geomorphic reasoning [28]. Statistical analysis in this regard helps in simplifying this issue in drainage basin studies through the use of multivariate statistical techniques such as: Principal Component Analysis (PCA), Cluster Analysis (CA), and Discriminant analysis (DA) [46] [47] [48] [49].

The large amounts of morphometric data pertaining to a large number of 
drainage basins, can be simplified and organized using these techniques. For example, Mather and Doornkamp [20] made a pioneer study on the application of multivariate statistical methods on a case study from southern Uganda. Eighteen morphometric parameters were measured and computed for 130 third-order drainage basins, and then analyzed to assess the morphometric properties of the resultant drainage basin groups. Moreover, multivariate statistical techniques have been widely employed in the hydrological and atmospheric sciences [50] [51]. Subyani et al. [25] employed morphometric analysis, multivariate statistics, and a SRTM digital elevation model (v.2) to illustrate the morphology, lithology, structure, and hydrological potential of arid watersheds. PCA, Q and R modes of Cluster Analysis were employed. Thus, the 18 morphometric descriptors pertaining to 10 arid watersheds in western Saudi Arabia, were analyzed and described in this way. The first three components accounted for $86 \%$ of the total variance in the original data and, revealed more details regarding the variable loadings and the degree of parameter significance. Belmar et al. [52] conducted a hydrological classification scheme of natural flow regimes, with characterization of similarity among flow regimes, to develop general criteria for flow regimes management (i.e., the assessment of environmental flows). Using different clustering techniques, a regionalization process was carried out to determine hydrologically homogeneous regions in data-scares watersheds [53]. Furthermore, Chiang et al. [54], and Mehaiguene et al. [55] carried out a research projects on hydrological stream flow regionalization (based on gauged watersheds using flow parameters) to establish hydrological regions according to the selected criteria. The attempt is to elaborate a methodology for extending hydrological information from gauged watersheds to ungauged ones.CA has also been used to delimit landscape types [56]. Factor analysis of mean annual stream flow in Minnesota [57] led to recognizing five hydrological regimes based on analysis of three periods extending from 1950 to 2008. Multivariate statistical methods were employed in the recent past in climatic regionalization [58]. Likewise, 21 morphometric parameters for 3833 first-order basins in the Siwalik (Nepal) were analyzed using PCA. This study recognizes different basin types based on morphometric properties of drainage basins. The association of first-order basins with structure, lithology, and uplift rates was assessed [27]. Moreover, clustering of geomorphic parameters of a watershed was carried out for hydrological modeling using PCA [29]. Raux et al. [26] performed a classification of drainage basins worldwide using multivariate analysis of hydro-morphometric parameters controlling their hydrosedimentary response. Additionally, morphometric analysis, Factor Analysis (FA) and CA, were employed to assess the input variables that are utilized in assessing flood parameters [59]. Miller et al. [46] employed CA) to classify 105 small drainage basins in Indiana, and five groups of basins were identified. It is concluded that morphometric parameters reflect an appropriate adjustment to the bedrock underlying the drainage basins. The Jordanian officials have planned to construct additional reservoirs across the W. $\mathrm{Mu}$ jib-Wala catchment in the future, whereas groundwater exploration is in pro- 
gress at present. In light of water resources scarcity in the country, the catchment constitutes a promising watershed for water resources development in the southern planning region. In our region also a statewide hydrological regionalization projects are significant for regional development planning. Thus, hydrological regimes can be recognized, each with runoff periods and duration. Applications of such techniques can be extended to carry out water resources planning schemes on regional and national levels.

It is intended in this research to:

1) Examine the intercorrelation among morphometric parameters, and perform regression analysis for the sub-basins vs. morphometric variables.

2) Explore the relationship of major components determined through PCA to the morphometric parameters, and to individual sub-watersheds to explain their contribution to the morphology of fourth-order sub-basins pertaining to the W. Mujib-Wala watershed.

3) Establish a classification scheme using CA to identify consolidated regions of sub-watersheds with reference to their individual relationships to the components and the original morphometric variables. The spatial patterns of subwatershed groups were analyzed with reference to lithology, tectonics and uplifting, and rejuvenation processes.

4) Test the validity of cluster groups or regions of sub-watersheds by means of DA, and to determine the nature of discriminant functions in relation to the character of components.

\section{Study Area}

A quantitative morphometric characterization and classification was carried out for W. Mujib-Wala sub-watersheds. The catchment is considered the second largest basin draining to the Jordan Rift and flows westward and discharges directly into the Dead Sea. The watershed extends between $30^{\circ} 39^{\prime}$ to $31^{\circ} 48^{\prime} \mathrm{N}$ latitudes, and $35^{\circ} 30^{\prime}$ to $36^{\circ} 30^{\prime} \mathrm{E}$ longitudes (Figure 1 ). The maximum and minimum elevation in the catchment is $1277 \mathrm{~m}$ (above sea level) east of Mazar town, and $-431 \mathrm{~m}$ (below sea Level) at the outlet of the wadi (Figure 2). The watershed is affected by successive stages of rejuvenation processes as a result of base-level changes along the Dead Sea, the lowest base level in the Jordan Rift [43]. Opposite to the outlet of W. Mujib-Wala, the Dead Sea attains a maximum depth of some $-401 \mathrm{~m}$ below the surface. At this point, the bottom of the Dead Sea is at $-815 \mathrm{~m}$ below sea level. In light of successive subsidence of the Dead Sea, and the resultant sea level changes, a high magnitude of rejuvenation phases affect the entire watershed and the sub-basins [44]. Thus, this has resulted in deeply dissected terrain, incised drainage, and over-steepened and interrupted slopes. Furthermore, the entire watershed suffers from serious geomorphic hazards, such as landslides, high sediment yield [60] [61], floods, and severe soil erosion. Slope categories and aspect maps of the catchment area were derived from ASTER DEM data (30 $\mathrm{m}$ resolution) using the surface analytical tool from the Arc GIS 10.1 software. A wide range of slope categories exist in the watershed, 

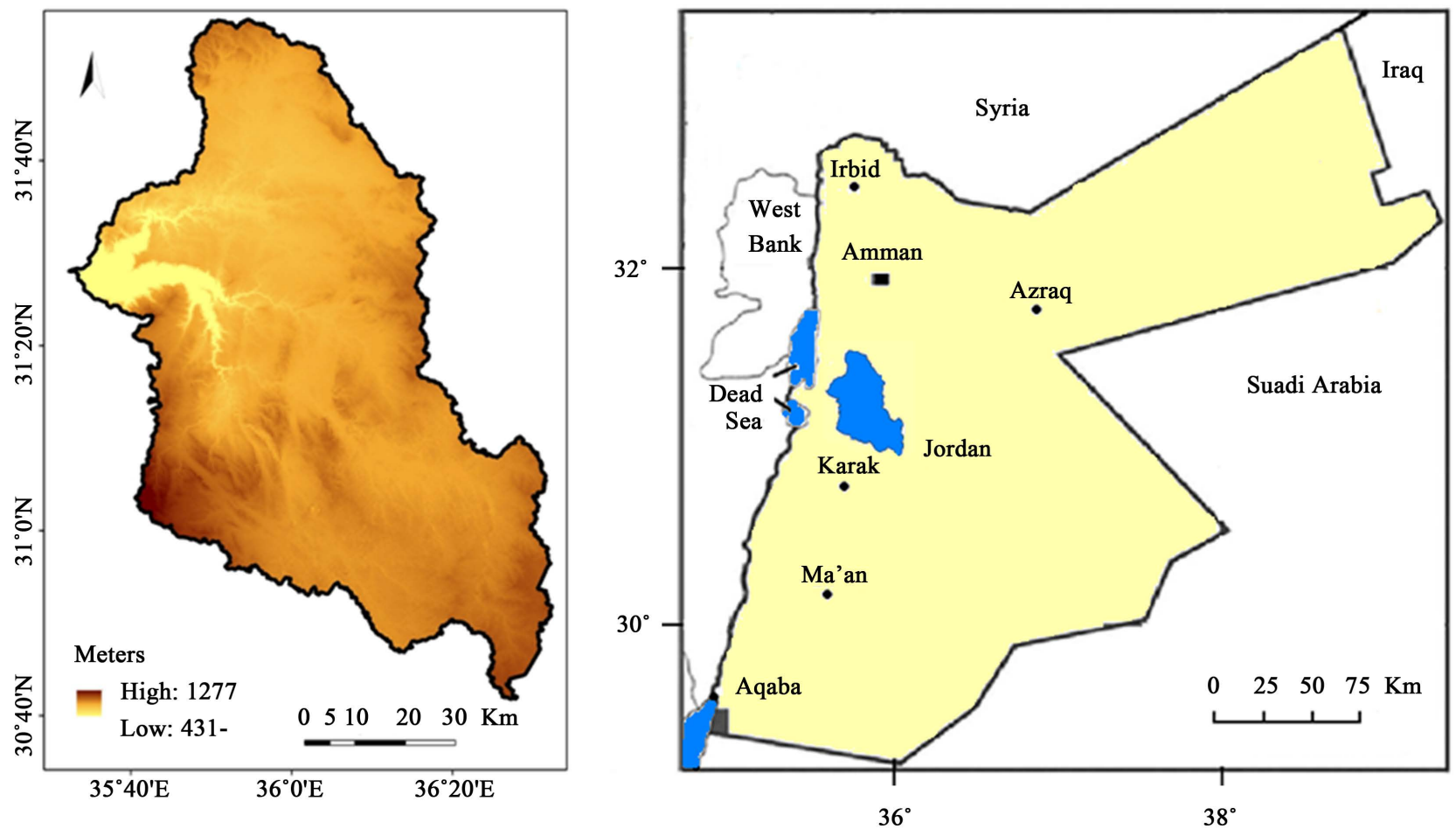

Figure 1. Location of the W. Mujib-Wala (the DEM \& map are based on [18]).

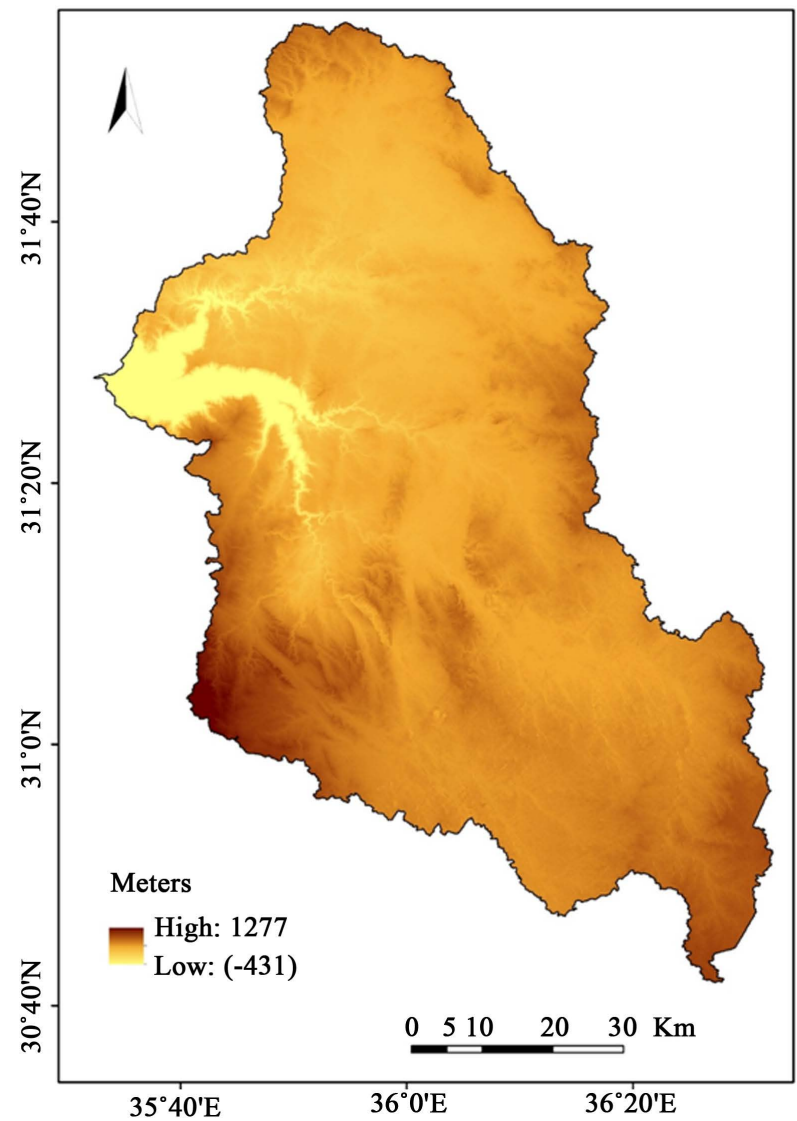

(a)

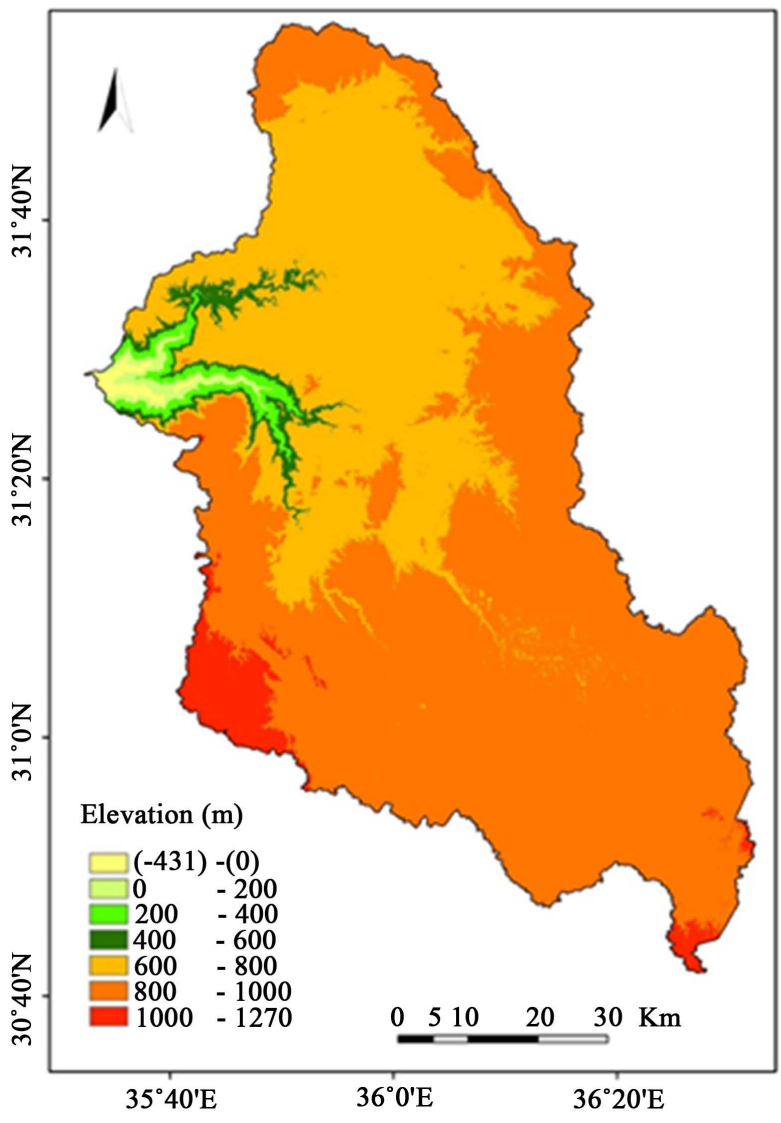

(b)

Figure 2. (a) DEM of the study catchment, and (b) Elevation (m). 
from gentle, semi-level, and undulating land $\left(0^{\circ}-5^{\circ}\right)$ in the east (Figure 3), to nearly vertical slopes surrounding the canyons that characterized the western area (including incised meanders) of W. Mujib-Wala, and the faulted-erosional escarpment overlooking the Dead Sea. Steep slopes dominate large parts of major tributaries of the W. Mujib-Wala. Consequently, slope gradients have a direct impact on surface runoff and geomorphic processes in the sub-watersheds. Aspect has a great influence on micro-climate, precipitation pattern, wind, exposure to sun, and thus evaporation rate, and vegetation type and density. Slopes facing the north and northeast, south, southwest and southeast are predominant in the western part of the watershed (Figure 4). Therefore, it is characterized by a lower evaporation rate, and thus, a higher moisture content. Rainfed agriculture is practiced on the summit surfaces and undulated land units, whereas irrigated agriculture dominates the wadi floor terraces, narrow floodplains and the upper part of the catchment. The climate of the high plateau is classified as dry Mediterranean, while the canyons and lower catchment close to the Dead Sea are arid. The mean annual rainfall ranges from $346 \mathrm{~mm}$ in the northwestern part of the catchment (Madaba area), to $164 \mathrm{~mm}$ in the middle part, and $335 \mathrm{~mm}$ in the southern high plateau. Rainfall is concentrated in winter (October to March). Temperatures exhibit large seasonal and diurnal variations, with daily temperatures ranging from a maximum $>40^{\circ} \mathrm{C}$ in August to a minimum of $-5^{\circ} \mathrm{C}$ in January. A wide range of rock types are exposed in the catchment, ranging from Cambrian sandstones to Quaternary fluvial and Lacustrine deposits. Along the lower parts of deeply incised courses to the west, the Kurnub sandstones (Lower

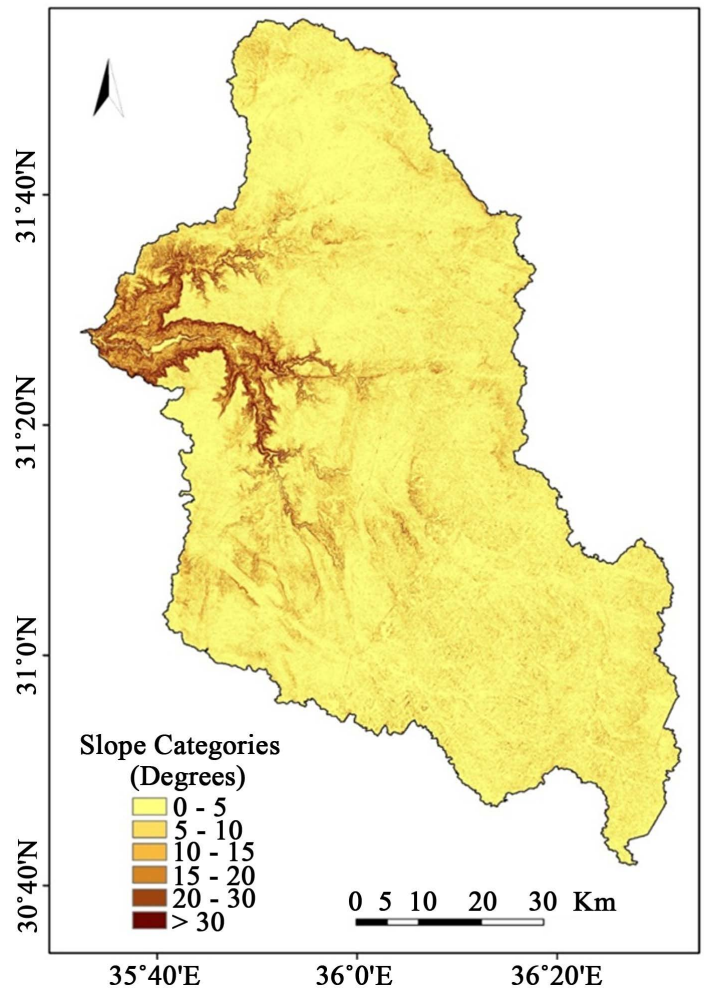

Figure 3. Slope categories. 


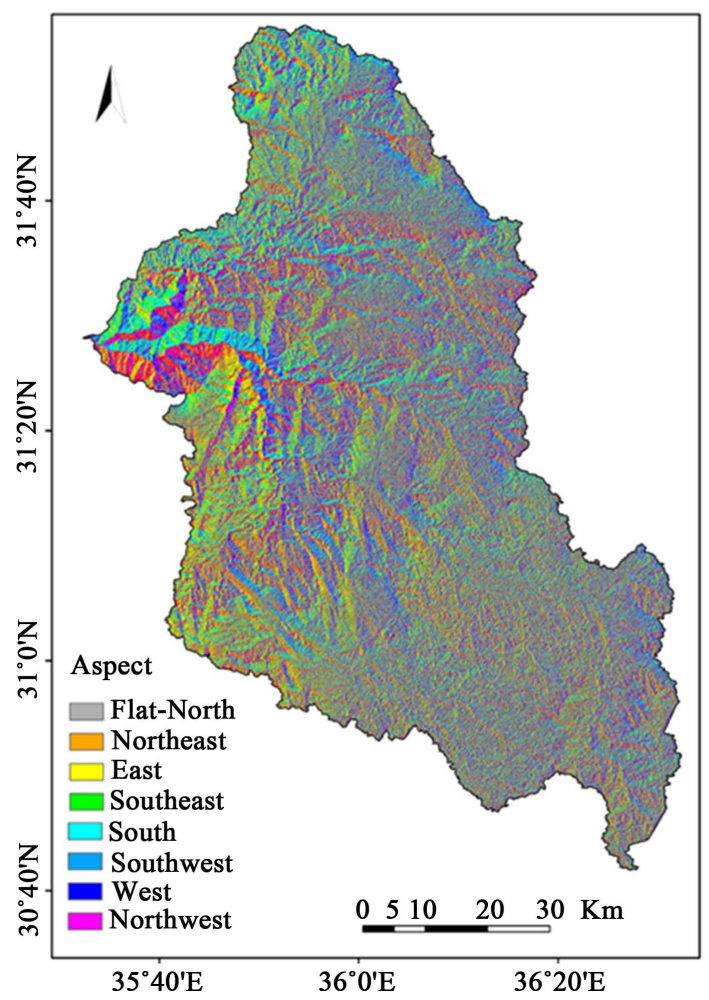

Figure 4. Slope aspects.

Cretaceous), the Nodular limestones, and the Echinoidal limestone units (Upper Cretaceous) are exposed. These lithological units are highly susceptible to landsliding. The Eocene-Senonian rock unit (mainly chert, limestone, chalk and marl) dominates the eastern and southern parts of the watershed [1] [62]. The weathered Shihan plateau basalt, the W. Wala, and W. Balue basalt are of Late Miocene/Early Pliocene age. Quaternary materials are restricted to three fluvial terrace levels which exist in central W. Mujib. These terraces are of early Holocene, Early and Middle Pleistocene age [63]. Rainfed farming (especially cereals, olive trees, and fruit trees) is practiced on the highlands, whereas, irrigated vegetable farming, green house farming, and poultry farms dominated the warm lowlands below W. Mujib and W. Wala dams. Agricultural land utilization occupies $7 \%$ of the total catchment. The western part of the watershed constitutes a major component of the W. Mujib Natural Reserve, and wadi beds accommodate palm trees, wild fig, tamarisk trees and oleander shrubs.

\section{Materials and Methods}

The quantitative morphometric characterization of W. Mujib-Wala (southern Jordan) is based on ASTER DEM (30 m spatial resolution), and topographic maps of scale 1:50,000 (20 m contour interval) obtained from the Royal Jordanian National Geographic Centre (RJNGC), Amman. They were then scanned, geo-referenced, and converted to the WGS-1984, Zone $36^{\circ} \mathrm{N}$ projection system using Arc GIS tools (v. 10.1). The entire W. Mujib-Wala and the 76 sub-watersheds were delineated initially using topo sheets. ASTER DEM was then em- 
ployed to delineate the final boundaries of the W. Mujib-Wala catchment and the 76 sub-basins (Figure 5). The drainage networks were also demarcated using the Arc Hydro tool provided by Arc GIS software. Twenty-two morphometric variables for the entire watershed and the 76 sub-basins, were extracted and calculated using ASTER DEM, Arc GIS software, and the mathematical equations developed by Horton [2], Strahler [3] [4] [5], Miller [7] and Schumm [8]. Among the morphometric parameters determined are: stream number $\left(\mathrm{N}_{\mathrm{u}}\right)$, stream length $\left(\mathrm{L}_{\mathrm{u}}\right)$, mean stream length $\left(\mathrm{L}_{\mathrm{sm}}\right)$, stream length ratio $\left(R_{1}\right)$, bifurcation ration $\left(R_{b}\right)$, mean bifurcation ratio $\left(R_{b m}\right)$, RHO coefficient $(P)$, length of overland flow $\left(\mathrm{L}_{\mathrm{o}}\right)$, basin area $(\mathrm{A})$, basin perimeter $(\mathrm{P})$, form factor $\left(\mathrm{R}_{\mathrm{f}}\right)$, drainage texture $\left(D_{t}\right)$, circularity ratio $\left(R_{c}\right)$, elongation ratio $\left(R_{e}\right)$, stream frequency (Fs), drainage density $\left(D_{d}\right)$, shape index $\left(B_{s}\right)$, constant of channel maintenance (C). compactness coefficient $\left(C_{c}\right)$, basin relief $\left(B_{h}\right)$, relief ratio $\left(R_{r}\right)$ ruggedness number $\left(\mathrm{R}_{\mathrm{n}}\right)$, dissection index $\left(\mathrm{D}_{\mathrm{is}}\right)$, and Melton ruggedness number $\left(\mathrm{M}_{\mathrm{rn}}\right)$ (Table 1). A number of multivariate statistical techniques were employed as an efficient tool to deduce the hydrological behavior through hydrological regionalization [54], and interactions between morphometric parameters in arid

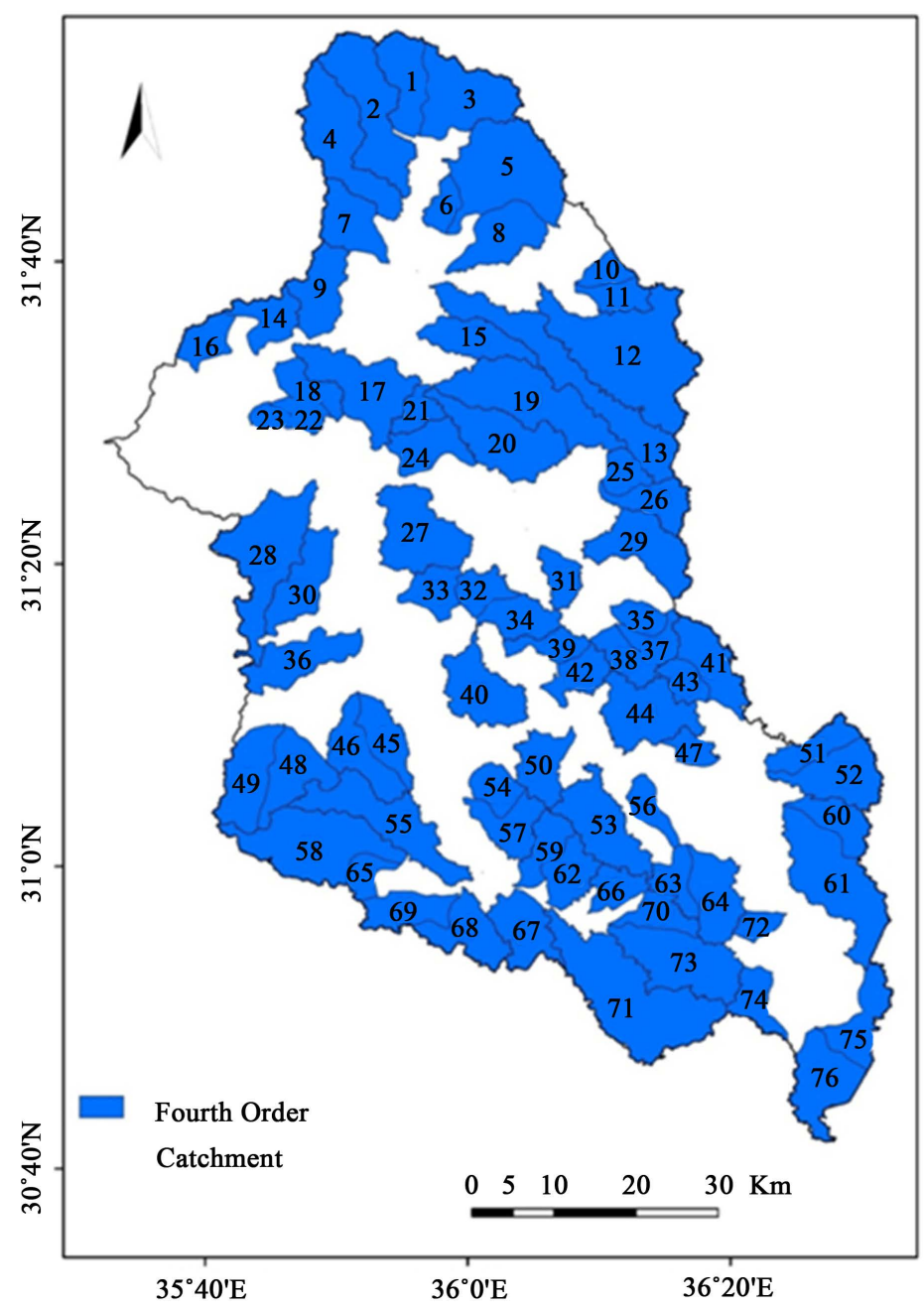

Figure 5. The 76 fourth-order sub-watersheds. 
Table 1. Morphometric variables employed in the present study.

\begin{tabular}{|c|c|c|c|}
\hline \multirow{3}{*}{ I } & \multicolumn{3}{|c|}{ Formula/Definition References } \\
\hline & \multicolumn{3}{|c|}{ Linear Parameters } \\
\hline & Stream order & Hierarchical Rank & [4] \\
\hline 1 & No. of streams $\left(\mathrm{N}_{\mathrm{u}}\right)$ & $\mathrm{N}_{\mathrm{u}}=\mathrm{N}_{1}+\mathrm{N}_{2}+\ldots \ldots \mathrm{N}_{\mathrm{n}}$ & {$[2]$} \\
\hline 2 & Stream length $\left(\mathrm{L}_{\mathrm{u}}\right)(\mathrm{Km})$ & $\mathrm{L}_{\mathrm{u}}=\mathrm{L}_{1}+\mathrm{L}_{2} \ldots \ldots \ldots \mathrm{L}_{\mathrm{n}(\mathrm{km})}$ & [5] \\
\hline 3 & Mean Stream Length $\left(\mathrm{L}_{\mathrm{sm}}\right)(\mathrm{Km})$ & $\mathrm{L}_{\mathrm{sm}}=\mathrm{L}_{\mathrm{u}} / \mathrm{N}_{\mathrm{u}}(\mathrm{Km})$ & {$[5]$} \\
\hline 4 & Stream Length ratio $\left(\mathrm{R}_{\mathrm{L}}\right)$ & $\begin{array}{c}R_{L}=L_{u} / L_{u}-1 \text {, where } L_{u}=\text { the total stream } \\
\text { length of order " } u \text { ", } L_{u}-1=\text { No. } \\
\text { of segment of the next lower order. }\end{array}$ & [2] \\
\hline & Bifurcation ratio $\left(\mathrm{R}_{\mathrm{b}}\right)$ & $\begin{aligned} \mathrm{R}_{\mathrm{b}}= & \mathrm{Nu} / \mathrm{Nu}+1=\text { No. of segment } \\
& \text { of the next higher order. }\end{aligned}$ & [8] \\
\hline & Mean bifurcation ratio $\left(\mathrm{R}_{\mathrm{bm}}\right)$ & $\begin{array}{l}\mathrm{R}_{\mathrm{bm}}=\text { average of bifurcation } \\
\text { ratio of Strahler all orders. }\end{array}$ & {$[4]$} \\
\hline 5 & RHO coefficient $(\rho)$ & $\rho=\mathrm{R}_{\mathrm{L}} / \mathrm{R}_{\mathrm{b}}$ & [2] \\
\hline 6 & Length of overland flow $\left(\mathrm{L}_{\mathrm{o}}\right) \mathrm{Km}$ & $\mathrm{L}_{\mathrm{o}}=1 / 2 \mathrm{D}_{\mathrm{d}}$, (or) $\mathrm{L}_{\mathrm{o}}=1 / \mathrm{D}^{\star} 2$ & [2] [66] \\
\hline II & \multicolumn{3}{|c|}{ Areal Parameters } \\
\hline 7 & Basin area $(\mathrm{A})\left(\mathrm{Km}^{2}\right)$ & Plan area of the watershed $\left(\mathrm{Km}^{2}\right)$ & [2] \\
\hline 8 & Basin Perimeter $(\mathrm{P})(\mathrm{Km})$ & Perimeter of the watershed $(\mathrm{Km})$ & [2] \\
\hline 9 & Form factor ratio $\left(\mathrm{R}_{\mathrm{f}}\right)$ & $\mathrm{R}_{\mathrm{f}}=\mathrm{A} / \mathrm{L}_{\mathrm{b}}^{2}$ & [2] [8] \\
\hline 10 & Drainage texture $\left(D_{t}\right)$ & $\mathrm{T}=\mathrm{N}_{\mathrm{u}} / \mathrm{P}$, where $\mathrm{N}_{\mathrm{u}}=$ Total no. of streams & [3] \\
\hline 11 & Circularity ratio $\left(\mathrm{R}_{\mathrm{c}}\right)$ & $\mathrm{R}_{\mathrm{c}}=4^{\star} \pi^{\star} \mathrm{A} / \mathrm{p}^{2}$ & {$[7]$} \\
\hline 12 & Elongation ratio $\left(\mathrm{R}_{\mathrm{e}}\right)$ & $\mathrm{R}_{\mathrm{e}}=1.128 \sqrt{A} / \mathrm{L}_{\mathrm{b}}$ & {$[8]$} \\
\hline 13 & Stream frequency $\left(\mathrm{F}_{\mathrm{s}}\right)$ & $\mathrm{F}_{\mathrm{s}}=\mathrm{N}_{\mathrm{u}} / \mathrm{A}$ & [2] [67] \\
\hline 14 & Drainage density $\left(\mathrm{D}_{\mathrm{d}}\right)\left(\mathrm{Km} / \mathrm{Km}^{2}\right)$ & $\mathrm{D}_{\mathrm{d}}=\mathrm{L}_{\mathrm{u}} / \mathrm{A}$ & {$[2]$} \\
\hline 15 & Shape Index $\left(B_{s}\right)$ & $\mathrm{B}_{\mathrm{s}}=\mathrm{L}_{\mathrm{b}}^{2} / \mathrm{A}$ & {$[2]$} \\
\hline 16 & $\begin{array}{l}\text { Constant of channel } \\
\text { maintenance }(\mathrm{C})\left(\mathrm{Km}^{2} / \mathrm{Km}\right)\end{array}$ & $\mathrm{C}=1 / \mathrm{D}_{\mathrm{d}}$ & [8] \\
\hline 17 & Compactness coefficient $\left(\mathrm{C}_{\mathrm{c}}\right)$ & $\mathrm{Cc}=0.2841$ * $\mathrm{P} / \mathrm{A}^{0.5}$ & {$[74]$} \\
\hline III & \multicolumn{3}{|c|}{ Relief Characteristics } \\
\hline 18 & $\begin{array}{l}\text { Basin relief }\left(B_{h}\right) \text { or } \\
\text { total relief }(H)(m)\end{array}$ & $\begin{array}{l}B_{h}=h-h_{1} \text {, where, } h=\text { maximum } \\
\text { height }(m) \text {, and } h_{1}=\text { minimum height }(m)\end{array}$ & {$[6]$} \\
\hline 19 & Relief ratio $\left(\mathrm{R}_{\mathrm{r}}\right)$ & $\begin{array}{c}\mathrm{R}_{\mathrm{r}}=\mathrm{H} / \mathrm{L}_{\mathrm{b}} \text {, where, } \mathrm{H}=\text { Total relief, and } \\
\mathrm{L}_{\mathrm{b}}=\text { basin length }\end{array}$ & {$[8]$} \\
\hline 20 & Ruggedness number $\left(\mathrm{R}_{\mathrm{n}}\right)$ & $\mathrm{R}_{\mathrm{n}}=\mathrm{D}_{\mathrm{d}} *\left(\mathrm{~B}_{\mathrm{h}} / 1000\right)$ & [3] \\
\hline 21 & Dissection index $\left(\mathrm{D}_{\mathrm{is}}\right)$ & $D_{\text {is }}=B_{h} / R a$, where $R a=$ absolute Relief $(m)$ & {$[8]$} \\
\hline 22 & $\begin{array}{l}\text { Melton rugged } \\
\text { ess number }\left(M_{r n}\right)\end{array}$ & $\begin{array}{l}M_{\mathrm{rn}}=\left(\mathrm{H}-\mathrm{h}_{1}\right) / \mathrm{A}^{0.5} \text { where, } \mathrm{H}=\text { maximum } \\
\text { height }(\mathrm{m}) \text {, and } \mathrm{h}_{1}=\text { minimum height }(\mathrm{m})\end{array}$ & [75] [76] \\
\hline
\end{tabular}

watersheds. Principal Component Analysis, Cluster Analysis, and Discriminant Analysis have been utilized in the analysis. The PCA method is often employed to analyze a large data matrix representing the 76 sub-watersheds including the 22 morphometric parameters in order to reduce the large number of variables to 
a small number of composite variables, or principal components (or factors) which are correlates with the morphometric parameters, and can be employed to describe the morphometric characteristics of watersheds and sub-watersheds. The technique is also designed to compute the correlation matrix to expose the highly loaded variables on each principal component, and how much the variability in the original variables is explained by each principal component. Eigen-value indicates how well each of the identified components fits with the data from all the morphometric attributes on all the PCs. The analysis of principal components can be restricted to all those components that have an eigen-value greater than one. CA has been employed to classify the 76 fourth-order sub-watersheds into different distinct homogenous groups of sub-basins based on the similarity coefficient.

The component scores of the 76 sub-basins are selected as input for clustering using Ward's minimum variance method, the most frequently used hierarchical clustering technique [54]. The results of CA are presented by linkage tree or dendrogram. Using PCA and CA methods, it was possible to recognize the structural relationships of the 22 morphometric parameters including the principal components [28]; and to identify categories of sub-basins based on both component scores and the original standardized morphometric parameters. DA was employed to test the validity of the cluster groups of sub-watersheds to determine if they are significantly different and to aid in explaining the regional differences among the fourth-order watersheds.

\section{Results and Discussions}

\subsection{Morphometric Assessment of W. Mujib-Wala Watershed}

Quantitative morphometric analysis was conducted for the entire catchment and the 76 sub-watersheds to assess the characteristics and properties of the drainage networks. Three aspects of drainage basin morphometry were measured: linear, areal and relief parameters. Twenty two morphometric variables were considered for characterization of the watershed and sub-watersheds and to understand the interrelationships among the morphometric parameters, and drainage basin development in relation to geology and structure, geomorphic and rejuvenation processes. The complex morphometric characteristics and the classification of sub-basins were evaluated. The measured morphometric descriptors of W. Mujib-Wala and the adopted mathematical equations are illustrated in Table 1. Table 2 displays the morphometric characteristics of the Wadi. The total drainage area of the entire catchment is $6571.4 \mathrm{~km}^{2}$, and the drainage pattern is sub-dendritic in the upper and eastern part of the watershed, and trellis in the central and western part of the catchment. The basin is classified as a seventhorder basin (according to [4]), with a length of $136.84 \mathrm{~km}$, and a perimeter of $564.484 \mathrm{~km}$. The total number of streams $(\mathrm{Nu})$ is 7948 , and the first-order streams account for $77.6 \%$ of the number of streams in the watershed. It is apparent that the total number of streams gradually decreases as the stream order increases. Generally, the higher the order, the longer the length of streams in 
Table 2. Morphometric characteristics of W. Mujib-Wala watershed.

\begin{tabular}{|c|c|c|c|c|c|c|c|c|c|}
\hline \multirow{2}{*}{$\begin{array}{c}\text { Par. } \\
\text { no. }\end{array}$} & \multirow{2}{*}{$\begin{array}{c}\text { Morphometric parameters } \\
\text { Linear Parameters }\end{array}$} & \multicolumn{8}{|c|}{ Stream order } \\
\hline & & & I & II & III & IV & $\mathrm{V}$ & VI & VII \\
\hline & Stream order & 7 & & & & & & & \\
\hline 1 & No. of streams $\left(\mathrm{N}_{\mathrm{u}}\right)$ & 7984 & 6167 & 1368 & 315 & 76 & 16 & 5 & 1 \\
\hline 2 & Stream length $\left(\mathrm{L}_{\mathrm{u}}\right)(\mathrm{Km})$ & 9216.34 & 4637.76 & 2235.5 & 1193.3 & 3595.46 & 263.72 & 227.4 & 63.2 \\
\hline \multirow[t]{5}{*}{3} & $\begin{array}{c}\text { Mean stream } \\
\text { length }\left(\mathrm{L}_{\mathrm{sm}}\right)(\mathrm{Km})\end{array}$ & & 0.752 & 1.634 & 3.788 & 7.835 & 16.482 & 45.4 & 63.2 \\
\hline & Stream Length ratio $\left(\mathrm{R}_{\mathrm{L}}\right)$ & & & $\mathrm{II} / \mathrm{I}$ & $\mathrm{III} / \mathrm{II}$ & IV/III & $\mathrm{V} / \mathrm{IV}$ & $\mathrm{VI} / \mathrm{V}$ & VII/VI \\
\hline & & & & 0.482 & 0.543 & 0.499 & 0.443 & 0.86 & 0.27 \\
\hline & Bifurcation ratio $\left(\mathrm{R}_{\mathrm{b}}\right)$ & & & $\mathrm{II} / \mathrm{I}$ & III/II & IV/III & $\mathrm{V} / \mathrm{IV}$ & $\mathrm{VI} / \mathrm{V}$ & VII/VI \\
\hline & & & & 4.508 & 4.343 & 4.145 & 4.750 & 3.200 & 5.000 \\
\hline 4 & $\begin{array}{l}\text { Mean bifurcation } \\
\quad \text { ratio }\left(\mathrm{R}_{\mathrm{bm}}\right)\end{array}$ & 4.324 & & & & & & & \\
\hline 5 & RHO coefficient $(\rho)$ & 0.120 & & & & & & & \\
\hline 6 & $\begin{array}{l}\text { Length of overland } \\
\text { flow }\left(L_{o}\right) \mathrm{Km}\end{array}$ & 0.701 & & & & & & & \\
\hline II & Area Parameters & & & & & & & & \\
\hline 7 & Basin area $(\mathrm{A})\left(\mathrm{Km}^{2}\right)$ & 6571.425 & & & & & & & \\
\hline 8 & Basin perimeter $(\mathrm{P})(\mathrm{Km})$ & 564.484 & & & & & & & \\
\hline 9 & Form factor ratio $\left(\mathrm{R}_{\mathrm{f}}\right)$ & 0.351 & & & & & & & \\
\hline 10 & Drainage texture $\left(D_{t}\right)$ & 1.696 & & & & & & & \\
\hline 11 & Circularity ratio $\left(R_{c}\right)$ & 0.259 & & & & & & & \\
\hline 12 & Elongation ratio $\left(\mathrm{R}_{\mathrm{e}}\right)$ & 0.668 & & & & & & & \\
\hline 13 & Stream frequency $\left(\mathrm{F}_{\mathrm{s}}\right)$ & 1.209 & & & & & & & \\
\hline 14 & $\begin{array}{l}\text { Drainage density }\left(D_{d}\right) \\
\qquad\left(\mathrm{Km} / \mathrm{Km}^{2}\right)\end{array}$ & 1.403 & & & & & & & \\
\hline 15 & Shape index $\left(B_{s}\right)$ & 2.849 & & & & & & & \\
\hline 16 & $\begin{array}{l}\text { Constant of channel } \\
\text { maintenance (C) }\end{array}$ & 0.713 & & & & & & & \\
\hline 17 & $\begin{array}{l}\text { Compactness } \\
\text { coefficient }\left(\mathrm{C}_{c}\right)\end{array}$ & 3.929 & & & & & & & \\
\hline III & Relief Characteristics & & & & & & & & \\
\hline 18 & $\begin{array}{l}\text { Basin relief }\left(B_{h}\right) \text { or } \\
\text { "Total relief" }(H)(m)\end{array}$ & 1708 & & & & & & & \\
\hline 19 & Relief ratio $\left(\mathrm{R}_{\mathrm{r}}\right)$ & 12.482 & & & & & & & \\
\hline 20 & Ruggedness number $\left(\mathrm{R}_{\mathrm{n}}\right)$ & 2.395 & & & & & & & \\
\hline 21 & Dissection index $\left(D_{\mathrm{is}}\right)$ & 1.338 & & & & & & & \\
\hline 22 & $\begin{array}{l}\text { Melton Ruggedness } \\
\text { Number }\left(M_{\mathrm{rn}}\right)\end{array}$ & 10.440 & & & & & & & \\
\hline
\end{tabular}


nature. A noticeable variation exists in $\left(\mathrm{R}_{\mathrm{L}}\right)$ values between the streams for different order of the W. Mujib-Wala catchment, and the 76 sub-basins, where it varies from 0.24 to 0.534 . Such variation might be attributed to morphological changes in relief and slope along the W. Mujib-Wala watershed, the influence of geological structure on geomorphic development of the wadi, and the progressive rejuvenation. The value of bifurcation ratios for the entire watershed and the 76 sub-watersheds are normal for basins in which the drainage system is distorted by structural disturbances. $R_{b}$ varies from 3.2 to 5.00 , with a mean of 4.32 for the entire catchment, while it varies from 2.2 to 11.3, with a mean of 3.9 for the 76 sub-watersheds. Drainage density $\left(D_{d}\right)$ is controlled mainly by relative relief and slope steepness. Low drainage density is achieved where the basin relief is high [5]. However, other factors determining $D_{d}$ are: the infiltration-capacity of the soil, and the resistance of surface materials against erosion. The $D_{d}$ value for the W. Mujib-Wala catchment is 1.403 (Table 2) which denotes a moderate to well-drained catchment. The presence of dissected topography and steep slopes with relatively impervious underlying lithology (i.e., the marly-clay unit and the marly limestone unit) exposed at the middle part of the catchment resulted in several springs out-flowing to the major courses of W. Mujib and W. Wala. The watershed exhibits a coarse drainage texture $\left(D_{t}\right)$, where the $D_{t}$ value is 1.7. Nevertheless, the presence of fragile slope regolith and soft rocks of low shearing resistance activate landsliding, and maximize soil erosion and sediment yield in the catchment [60] [61]. With reference to the ratio between basin perimeter (P) and basin area (A) (11.6:1), the water divide of W. Mujib-Wala catchment is considered to be irregular. The stream frequency $\left(\mathrm{F}_{\mathrm{s}}\right)$ value of the watershed is 1.21 , and for the 76 sub-watersheds, it range from 0.293 to 1.632. Low $F_{s}$ values indicate that a relatively low infiltration rate of surface water is assumed; thus, the groundwater potential is relatively low. Miller [7] reported that drainage basins with a range of circularity ratio $\left(\mathrm{R}_{\mathrm{c}}\right)$ of 0.4 to 0.5 are depicted as strongly elongated and at the youth stage of geomorphic evolution. The $R_{c}$ value of the W. Mujib-Wala catchment is 0.259 , and the form factor $\left(\mathrm{R}_{\mathrm{f}}\right)$ value is 0.351 (Table 2). Low $R_{f}$ value directly indicates that low peak flows of long duration are expected; thus, such an elongated watershed is highly vulnerable to flooding risks compared with a circular-shaped watershed area. Additionally, Strahler [5] stated that values of elongation ratio $\left(R_{e}\right)$ vary between 0.6 to 1.0 over a wide range of climatic, environmental and geological conditions. The elongation ratio for the entire W. Mujib-Wala is 0.668 , whereas the values pertaining to the 76 sub-watersheds range from 0.425 to 1.015 . Such values are indicative of elongated shape, and associated with steep slopes and high rugged relief. The basin relief $\left(B_{h}\right)$ of W. Mujib-Wala catchment is $1708 \mathrm{~m}$. A high $B_{h}$ value denotes a high potential erosional energy and active slope processes of the drainage system. Due to progressive lowering of the base level (the Dead Sea), and tectonic activity, the W. Mujib-Wala retained rapid down cutting and incision along major courses during its geomorphic evolution, giving rise to a spectacular canyons reminiscent of the Colorado Grand Canyon, and rough dissected terrain. High 
soil erosion rates and sediment yield, and landslide movements are important geomorphic processes at present. The dissection index $\left(D_{i s}\right)$ for W. Mujib-Wala watershed is 1.338 which clearly indicates that the watershed is extremely dissected as a result of Successive rejuvenation phases, and the youth-age stage of geomorphic development. As expected the hypsometric integral for the entire catchment is $87 \%$ and the hypsometric curve exhibits a remarkably convex upward curve [19]. The watershed is also prone to severe soil erosion loss, shallow and deep seated landslides, and is of high liability to reach peak discharge following heavy rainstorms. Based on $\mathrm{D}_{\text {is }}$ classification, the W. Mujib-Wala is considered extremely dissected; consequently, it is of high susceptibility to erosion, incised channel erosion and mass movement activity.

\subsection{Morphometric Assessment of the 76 Sub-Watersheds}

The delimited 76 sub-basins for regionalization process are of fourth-order basins according to Strahler's ordering system [3] [4] [5]. Noticeable variation exists in their morphometric properties based on linear, areal and relief parameters representing the sub-watersheds. The total number of streams varied from 23 stream segments (sub-basin 73) to 238 for sub-watershed 13 (Appendix, Table A1). Such variation in $\mathrm{N}_{\mathrm{u}}$ counts is attributed to the variation in rejuvenation and erosion rates between the western and eastern parts of the catchment. The total stream length $\left(\mathrm{L}_{\mathrm{u}}\right)$ of W. Mujib-Wala is $9216.25 \mathrm{~km}$, while the first-order streams measured $4637.67 \mathrm{~km}$, and account for $50.3 \%$ of the total stream length. By contrast, the stream lengths of the sub-watersheds range from $14.4 \mathrm{~km}$ (subwatershed no. 24) to $265.1 \mathrm{~km}$ for sub-basin no. 13 (Appendix, Table A1). All the 76 sub-basins are morphologically varied as a result of the paleoclimate, tectonic activity and rejuvenation processes which were activated for a long geological time. Thus, the stream lengths and numbers, slope steepness and the size of sub-watersheds were determined.

The mean stream length for the study watershed vary from $0.752 \mathrm{~km}$ (for the $1^{\text {st }}$ order) to $63.2 \mathrm{~km}$ (for the $7^{\text {th }}$ order) (Table 2). Whereas the $\mathrm{L}_{\mathrm{sm}}$ for the 76 sub-basins ranges from 0.847 to $6.48 \mathrm{~km}$ (Appendix, Table A1). It is obvious that $\mathrm{L}_{\mathrm{sm}}$ for any given order $(\mathrm{u})$ is greater than that of the lower order, and less than that of its next higher order in both the W. Mujib-Wala and the 76 subwatersheds [30]. The average minimum stream length ratio $\left(R_{L}\right)$ is 0.167 , while the average maximum value is 5.746 . The variation of $R_{L}$ values between stream order 4 and 2, is attributed to high relief and slope steepness. The high values of $R_{L}$ indicates the youthful stage of geomorphic development of landforms. It is argued that $R_{b}$ values can be correlated with the hydrological characteristics of $a$ catchment. High $R_{b}$ values reveal high overland flow, whereas low $R_{b}$ values refer to high infiltration rate and the formation of fewer channels. Therefore, high $R_{b}$ values denote an early hydrograph peak with a high potential of susceptibility to flash flooding as a result of repetitive rainstorms in southern Jordan [30] [63] [64]. The study catchment thus testifies to recurrent severe flooding at present. The $R_{b}$ values for the entire watershed range from 3.2 to 5.0 , and the mean bi- 
furcation ratio is 4.32 (Table 2). However, $R_{b}$ values are relatively high for sub-watersheds occupying the western part of the catchment, and generally the $R_{b}$ values range from 2.2 to 11.3 for the 76 sub-basins with a mean of 3.9.The RHO coefficients for the sub-watersheds vary from 0.090 to 0.495 . Such values indicate that several sub-basins have relatively high hydrologic storage during flooding. The length of overland flow for the W. Mujib-Wala catchment is 0.701 $\mathrm{km}$, and for the 76 sub-basins varies from $0.594 \mathrm{~km}$ to $0.885 \mathrm{~km}$. Variation in $\mathrm{L}_{\mathrm{o}}$ values may be attributed to the variation in slope, lithology, vegetation cover, rainfall intensity and infiltration capacity.

The largest sub-watersheds occupy the eastern and southeastern part of W. Mujib-Wala catchment. Large watersheds with high relative relief create a greater discharge and vice versa. The areas of sub-basins range from $18 \mathrm{~km}^{2}$ to 185 $\mathrm{km}^{2}$. The perimeter is also an important parameter in quantitative morphometry, and can be employed as indicator of drainage basin size and shape. The perimeter of the 76 sub-basins range from $18.4 \mathrm{~km}$ to $153.5 \mathrm{~km}$. The $\mathrm{R}_{\mathrm{f}}$ value for the entire watershed is 0.351 , whereas the values of $R_{f}$ for the sub-basins range from 0.086 to 0.747 . However, most of the sub-basins tend to be elongated with low peak flow of longer duration. Further, the drainage texture for the 76 subwatersheds ranges from 0.449 to 2.719 . According to Smith's [6] classification of $D_{t}$, the drainage texture is relatively coarse. It is concluded that circularity ratio $\left(R_{c}\right)$ is equal to unity when the catchment's shape is a perfect circle and decreases to 0.785 when the basin is square. It continues to decrease to the extent to which the watershed becomes elongated. $R_{c}$ in influenced by length and frequency of streams, geological structure, climate, land use/cover, topography and slope of the basin [7]. The circularity ratio of the entire watershed is 0.259 (Table 2) and for the sub-watersheds ranges from 0.065 to 0.755 . Most of the sub-basins are described as strongly elongated. The elongated ratio of the Mujib-Wala catchment is 0.668 , and it is therefore considered elongated. Similarly, the $R_{e}$ values for the 76 sub-watersheds range from 0.331 to 0.911 . The elongated shape of catchments implies a young stage of geomorphic development caused by neotectonic activity. Most of the sub-basins are elongated and more elongated. The $R_{e}$ values range from 0.331 to $<0.6$ (Appendix, Table A1), which indicate that these sub-basins are of steep slopes, high relief with low infiltration capacity.

Stream frequency $\left(\mathrm{F}_{\mathrm{s}}\right)$ is an indication of drainage texture for a given catchment. This parameter is positively correlated with $D_{d}$ values of a watershed. Therefore, any increase in stream population is connected to that of drainage density [65] [66]. High $\mathrm{F}_{\mathrm{s}}$ values denote more percolation in the underlying materials, and hence more groundwater potential [67]. The values of stream frequency for the 76 sub-basins range from $0.293 \mathrm{~km}^{-2}$ to $1.771 \mathrm{~km}^{-2}$. Such values indicate that the W. Mujib-Wala catchment is relatively of high runoff. By contrast, $D_{d}$ is a measure of fluvial dissection, runoff potential and closeness of spacing of channels for a given catchment [2] [68]. The drainage density of a sub-watershed relates to intrinsic factors such as: distribution and length of the stream segment, relief and slope, lithology, climate, and infiltration capacity [6]. 
High $D_{d}$ values denote a relatively high density of stream segments, high runoff, a quick stream response and consequently a low infiltration rate. By contrast, low drainage density indicates low runoff and high infiltration [69]. The values of drainage density related to the 76 sub-basins vary from $1.2\left(\mathrm{~km} / \mathrm{km}^{2}\right)$ to 1.77 $\mathrm{km} / \mathrm{km}^{2}$ (Appendix, Table A1). With reference to the classification of drainage density proposed by Deju [70], most of the sub-basins are categorized under medium drainage density. High $B_{s}$ values indicate that the length of watershed is high, thus more groundwater recharge is expected. Moreover, lower $B_{s}$ values imply high susceptibility to peak flooding discharge associated with flash flood hazards [71] [72]. The shape factor for the entire W. Mujib-Wala is 2.849 (Table 2 ), whereas, the $B_{s}$ values for the 76 sub-watersheds range between 1.26 and 11.6, but most of the sub-basins have a low values, i.e., in the range of 1.255 - 3.156, with the possibility of flash flooding occurring. The $\mathrm{C}$ parameter denotes the number of $\mathrm{km}^{2}$ of sub-basin surface required to develop and sustain $1 \mathrm{~km}$ of channel length [45] [73]. The higher the $C$ value of a sub-catchment indicates the higher degree of structural distortion and high permeability of bedrock. Whereas, low $\mathrm{C}$ values $(<0.5)$ refers to fewer structural disturbances and low permeability [72]. The values of $\mathrm{C}$ parameter for the 76 sub-basins vary from 0.565 to 0.841 . Low compactness coefficient $\left(\mathrm{C}_{c}\right)$ values imply more elongation and high erosion in a catchment. The $\mathrm{C}_{\mathrm{c}}$ values for the W. Mujib-Wala catchment is 3.929, and for the sub-watersheds it exceeds 3 which indicates high erosion rates and sediment yield.

The basin relief $\left(B_{h}\right)$ of the entire catchment is 1708 (Table 2). Such a $B_{h}$ value indicates a high potential erosional energy of the drainage basin. Due to progressive lowering of the Dead Sea level and tectonic activity, the W. Mujib-Wala entailed rapid incision and down cutting during its geomorphic evolution, thus giving rise to the present dissected topography and rough terrain. The $B_{h}$ values for the 76 sub-watersheds range from $93 \mathrm{~m}$ to $880 \mathrm{~m}$. It is obvious that some sub-basins are characterized by a high $\mathrm{B}_{\mathrm{h}}$ values, which indicate landslides activity and severe soil erosion across these sub-basins. The relief ratio ( $\mathrm{Rr}$ ) for $\mathrm{W}$. Mujib-Wala watershed is 12.482 , and for the sub-watershed, it varies from 7.335 to 76.085 (Appendix, Table A1). These high figures are a result of steep slopes and great relative relief, thus denote high erosive energy. Patton and Baker [75] employed the ruggedness number $\left(R_{n}\right)$ parameter to assess the flash flood potential of small drainage basins. $R_{n}$ also expresses the geometric characteristics of the watershed. The ruggedness number of the 76 sub-basins vary from 0.132 to 1.196. A low value of $R_{n}$ indicates subdued morphology. Whereas high values imply sharp morphological expression. The dissection index $\left(D_{\text {is }}\right)$ values for the sub-watersheds vary from 0.103 which indicates the presence of rolling topography at the eastern margins of W. Mujib-Wala watershed (where remnants of erosion surfaces exist) and 0.829 which refers to extremely dissected terrain in the western part of the catchment, due to intense rejuvenation. The Melton ruggedness number $\left(M_{r n}\right)$ [76] as a slope index that affords specialized representation of relief ruggedness within a catchment. It enables one to distinguish the 
basins prone to flood hazard from those subjected to debris floods or debris flow [77]. The $M_{\mathrm{rn}}$ values for the sub-watersheds range from 0.013 to 0.0846 (Appendix, Table A1). Low $\mathrm{M}_{\mathrm{rn}}$ values suggest that the catchment is prone to flooding hazards rather than debris flow whereas, high $\mathrm{M}_{\mathrm{rn}}$ values imply that debris flow is expected.

\subsection{Statistical Analysis}

\subsubsection{Pearson Correlation between Morphometric Parameters}

The level of correlation between each pair of the 22 parameters is displayed in (Table 3). Correlation analysis indicates that most morphometric parameters of W. Mujib-Wala sub-watersheds illustrate a positive correlation with each other, which implies that these parameters are interdependent. In the genetic sense of the term, all geomorphic parameters are considered dependent parameters. The stream length within a catchment for example, may depend on the size or area of the basin, but the size of the catchment is likely to be dependent upon the length of its streams. It is also concluded that within the correlation matrices computed

Table 3. Pearson correlation coefficient matrix for the 22 parameters (bold correlations are significant at $p<0.050$ ).

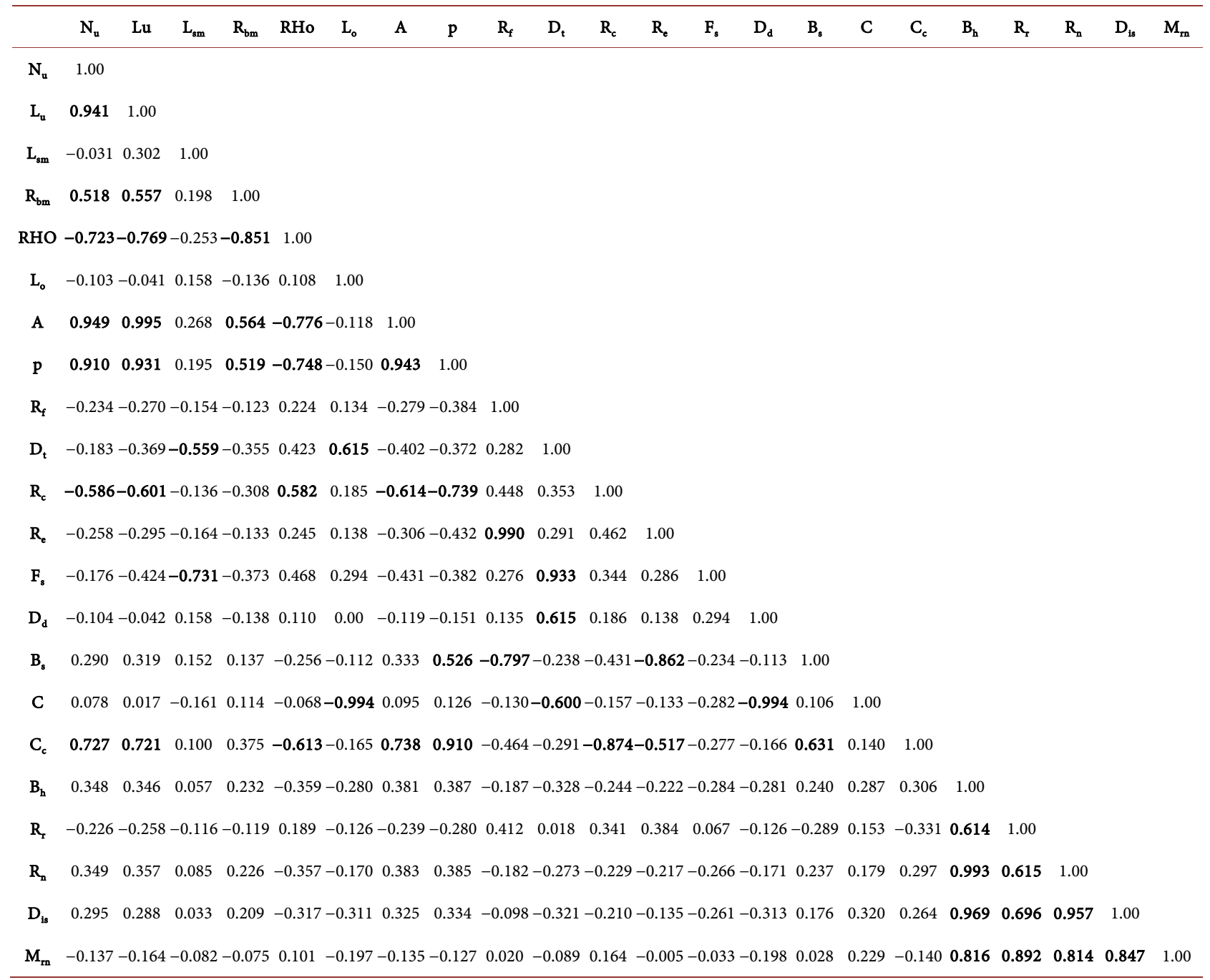


in drainage basin morphometric studies, there is no one dependent variable, but all variables are dependent on each other, are closely interconnected and have strong influence one over the other. That is true except in the few examples where physical factors play a prominent role in establishing them as independent. Strong ( $\mathrm{R}=0.8$ to 0.9 ), or good and moderate correlation often exists between basin area $(A)$, and variables related to stream length $\left(L_{u}\right)$ which denote that an increase in basin size is associated with an increase in the number and length of streams. Moreover, good ( $\mathrm{R}=0.7$ to 0.8 ) and moderate $(\mathrm{R}=0.5$ to 0.7$)$ negative correlations also exist. Strong positive correlations exist between the sub-watershed area and all the variables related to linear morphometric parameters ( $\mathrm{R}$ of $(\mathrm{A})$ vs. $\left(\mathrm{N}_{\mathrm{u}}\right)=0.979$; $\mathrm{R}$ of $(\mathrm{A})$ vs. $\left(\mathrm{L}_{\mathrm{u}}\right)=0.995$; $\mathrm{R}$ of $(\mathrm{A})$ vs. $\left.(\mathrm{P})=0.949\right)$. Furthermore, a good correlation exists between $(A)$ and $C c(R=0.738)$, and moderate correlation is observed between $(A)$ and $\left(R_{b m}\right)(R=0.564)$. In addition, strong positive correlations occur between $\mathrm{N}_{\mathrm{u}}$ and $\mathrm{L}_{\mathrm{u}}$ and $\mathrm{P}(\mathrm{R}=0.941$ and 0.910 respectively). A good and moderate correlations is also observed between $\mathrm{Nu}$ with $C_{c}$ and $R_{b m}(R=0.729$ and 0.518 respectively). Significant strong correlations occur between $B_{h}$ with $R_{n}, D_{i s}$, and $M_{r n}(R=0.993 ; 0.969$ and 0.816 respectively), and Mrn with $R_{n}, D_{i s}$, and $R_{r}(R=0.913 ; 0.847$, and 0.892 respectively). A distinct inter-correlation exists between $\mathrm{L}_{\mathrm{u}}$ with $\mathrm{P}(\mathrm{R}=0.931)$, $\mathrm{Lu}$ with $\mathrm{C}_{\mathrm{c}}(\mathrm{R}=$ 0.721), $P$ with $C_{c}(R=0.910), R_{f}$ with $R_{e}(R=0.990)$, and $D_{t}$ with $F_{s}(R=0.933)$. Moderate correlation is provided by $\mathrm{D}_{\mathrm{t}}$ with $\mathrm{L}_{\mathrm{o}}$ and $\mathrm{D}_{\mathrm{d}}(\mathrm{R}=0.615$ and 0.615 respectively), and $R_{r}$ with $R_{n}$ and $D_{i s}(R=0.615$ and 0.696$)$ respectively. It is obvious that the above levels of correlations are reflected in the results of the Principal Component Analysis. This is attributed to the computation of the significant component, where taken into consideration are the levels and directions of correlation: positive or negative [20].

\subsubsection{Spatial Patterns of Sub-Watersheds: PCA}

PCA is used for data reduction through minimizing the number of parameters to a small number of components, and exposing latent structure in the relationships between parameters (classifying variables, or differentiating characteristics). It is employed to examine the patterns of relationships amongst many dependent variables, with the aim of discovering something about the nature of the independent parameters that affect them, even though those independent parameters may not be directly measured. Principal Component Analysis considers the total variance and makes no distinction between common and unique variance. PCA consists of several steps: (i) extracting initial components, (ii) determining how many components to employ in the final solution, and (iii) rotating the original variable space so as to maximize the variance of the resultant components. PCA have been employed as the method of initial component extraction. Eigen-values were also used to determine how many components to use in the final solution, including all components with an eigen-value $>1.0$. Then, a normalized varimax rotation was applied for the final solution, and used to compute component loadings between the original parameters and the final components. The higher the loadings, the stronger the correlation. By plotting 
each component loadings onto a 3-dimensional scatterplot representing Component 1 through 5, it appears that using a cut-off of 0.70 creates a clustering break of parameters within each of the five components (Figure 6). PCA resulted in five major components that accounts for $90.4 \%$ of the total variance explained by the 22 morphometric parameters (Table 4). In this Table, eigenvalues, variance proportion, and cumulative variance proportion are shown. According to Table 4, it is clear that the first three $\mathrm{PC}_{\mathrm{s}}$ and the five $\mathrm{PC}_{\mathrm{s}}\left(\mathrm{PC}_{1}\right.$ $\mathrm{PC}_{3}$ and $\mathrm{PC}_{1}-\mathrm{PC}_{5}$ ) account for $63.93 \%$ and $90.4 \%$ of the total variance proportion of input parameters. Furthermore, the screen plot (Figure 7) shows that the first five components are the best choice.

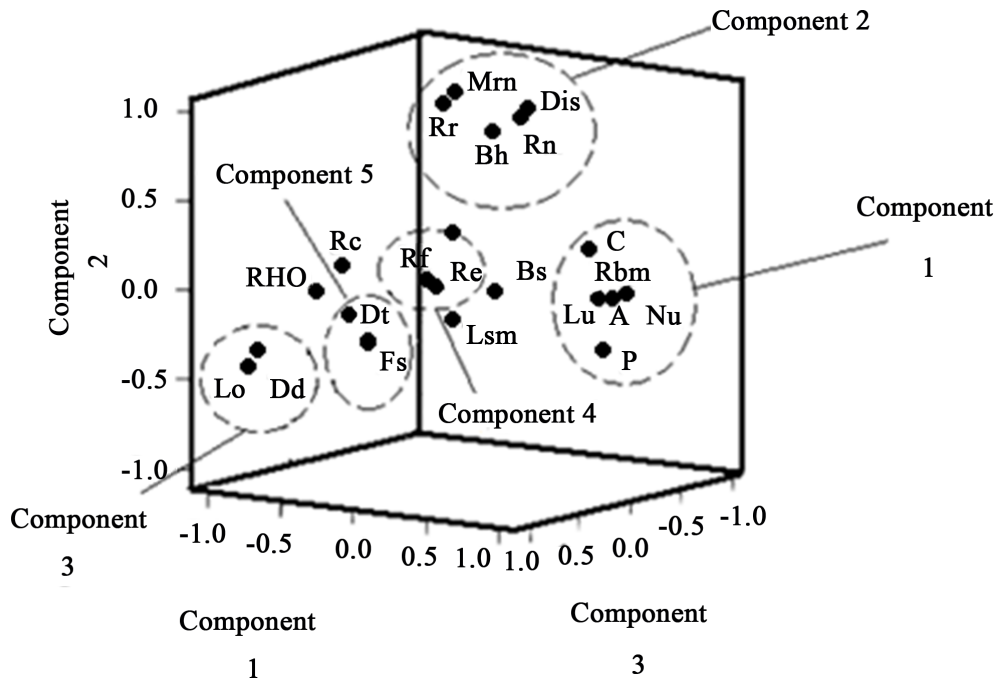

Figure 6. Clustering of five components, or sub-basins regions using component loads.

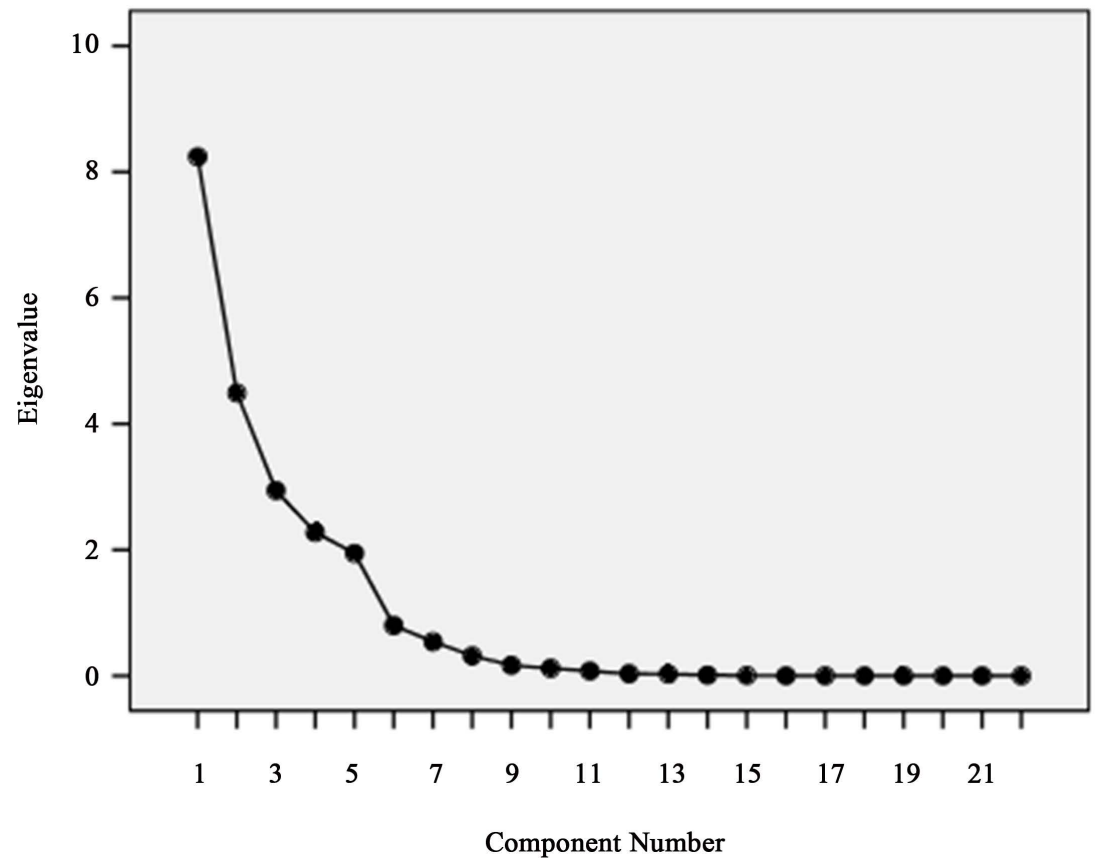

Figure 7. Scree plot illustrating the 5-component solution resulting from PCA. 
Table 4. Total variance explained by the component.

\begin{tabular}{|c|c|c|c|c|c|c|c|c|c|}
\hline \multirow{2}{*}{ 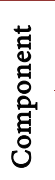 } & \multicolumn{3}{|c|}{ Initial eigenvalues } & \multicolumn{3}{|c|}{$\begin{array}{l}\text { Extraction sums } \\
\text { of squared loadings }\end{array}$} & \multicolumn{3}{|c|}{$\begin{array}{c}\text { Rotation sums } \\
\text { of squared loadings }\end{array}$} \\
\hline & Total & $\begin{array}{c}(\%) \text { of } \\
\text { Variance }\end{array}$ & $\begin{array}{c}\text { Cumulative } \\
\text { (\%) }\end{array}$ & Total & $\begin{array}{c}\% \text { of } \\
\text { Variance }\end{array}$ & $\begin{array}{c}\text { Cumulative } \\
(\%)\end{array}$ & Total & $\begin{array}{c}(\%) \text { of } \\
\text { Variance }\end{array}$ & $\begin{array}{c}\text { Cumulative } \\
(\%)\end{array}$ \\
\hline 1 & 8.241 & 37.458 & 37.458 & 8.241 & 37.458 & 37.458 & 6.292 & 28.599 & 28.599 \\
\hline 2 & 4.489 & 20.404 & 57.862 & 4.489 & 20.404 & 57.862 & 4.318 & 19.626 & 48.225 \\
\hline 3 & 2.941 & 13.367 & 71.229 & 2.941 & 13.367 & 71.229 & 3.455 & 15.704 & 63.929 \\
\hline 4 & 2.276 & 10.344 & 81.573 & 2.276 & 10.344 & 81.573 & 3.366 & 15.302 & 79.230 \\
\hline 5 & 1.946 & 8.843 & 90.416 & 1.946 & 8.843 & 90.416 & 2.461 & 11.186 & 90.416 \\
\hline 6 & 0.799 & 3.633 & 94.049 & & & & & & \\
\hline 7 & 0.542 & 2.464 & 96.513 & & & & & & \\
\hline 8 & 0.319 & 1.452 & 97.965 & & & & & & \\
\hline 9 & 0.166 & 0.754 & 98.719 & & & & & & \\
\hline 10 & 0.120 & 0.543 & 99.263 & & & & & & \\
\hline 11 & 0.075 & 0.343 & 99.605 & & & & & & \\
\hline
\end{tabular}

Moreover, the most effective variables in $\mathrm{PC}_{\mathrm{s}}$ formation are shown by bold font in Table 5. It is clear that stream number $\left(\mathrm{N}_{\mathrm{u}}\right)$, stream length $\left(\mathrm{L}_{\mathrm{u}}\right)$, mean bifurcation ratio $\left(\mathrm{R}_{\mathrm{bm}}\right)$, basin area $(\mathrm{A})$, basin perimeter $(\mathrm{P})$ and constant of channel maintenance $\left(C_{c}\right)$ have the most variance proportions (28.6\%), and exert the greatest effect on the first component. Furthermore, basin relief $\left(B_{h}\right)$, relief ratio $\left(R_{r}\right)$, ruggedness number $\left(R_{n}\right)$, dissection index $\left(D_{\text {is }}\right)$, and Melton ruggedness number $\left(\mathrm{M}_{\mathrm{rn}}\right)$ parameters have the greatest effect on the second component $\left(\mathrm{PC}_{2}\right)$, which comprises $19.61 \%$ of variance proportions. Moreover, $\mathrm{PC}_{3}$ is strongly associated by length of overland flow $\left(\mathrm{L}_{\mathrm{o}}\right)$, drainage density $\left(\mathrm{D}_{\mathrm{d}}\right)$, and constant of channel maintenance (C). Parameters such as form factor $\left(\mathrm{R}_{\mathrm{f}}\right)$ and elongation ratio $\left(\mathrm{R}_{e}\right)$ exert the strongest effect on the $\mathrm{PC}_{4}$, whereas, variables such as drainage texture $\left(D_{t}\right)$ and stream frequency $\left(F_{s}\right)$ have the greatest impact on the $\mathrm{PC}_{\mathrm{s}}$. Variable loadings show that three components are an expression of drainage network and geometry, relief characteristics, and drainage texture morphometric parameters. These components together explain $63.93 \%$ of the total variance, whereas the fourth and the fifth components represent drainage texture parameters (Table 4). However, the contribution of $\mathrm{PC}_{4}$ and $\mathrm{PC}_{5}$ are noticeably smaller than those of $\mathrm{PC}_{1}-\mathrm{PC}_{3}$, and most of the parameters exhibit loading values $>0.9$. The cumulative explanation is found to be only $24.4 \%$. Principal Component 1 accounts for $28.6 \%$ of the variance of the 22 morphometric parameters. The component loadings reveal that $\mathrm{PC}_{1}$ describes parameters related to the sub-watersheds drainage network $\left(\mathrm{N}_{\mathrm{u}}, \mathrm{L}_{\mathrm{u}}, \mathrm{R}_{\mathrm{bm}}\right.$, $\mathrm{A}$, and $\left.\mathrm{P}\right)$. Consequently, $\mathrm{PC}_{1}$ is labeled as a "sub-watershed size" component. The second component is predominantly represented positively by the relief parameters $\left(B_{h}, R_{r}\right.$, $R_{n}, D_{i s}$, and $M_{r n}$ ). This component reflects the "slope steepness and relief". $\mathrm{PC}_{3}$ corresponds to the length of overland flow $\left(\mathrm{L}_{\mathrm{o}}\right)$, drainage density $\left(\mathrm{D}_{\mathrm{d}}\right)$, and com- 
Table 5. Varimax rotated components loading matrix.

\begin{tabular}{|c|c|c|c|c|c|}
\hline \multirow{2}{*}{ Morph. No. } & \multicolumn{5}{|c|}{ Component } \\
\hline & 1 & 2 & 3 & 4 & 5 \\
\hline $\mathrm{Nu}$ & 0.949 & 0.073 & -0.031 & -0.102 & 0.134 \\
\hline $\mathrm{L}_{\mathrm{u}}$ & 0.935 & 0.058 & 0.047 & -0.121 & -0.181 \\
\hline $\mathrm{L}_{\mathrm{sm}}$ & 0.095 & -0.019 & 0.226 & -0.092 & -0.903 \\
\hline $\mathbf{R}_{\mathrm{bm}}$ & 0.663 & 0.038 & -0.087 & 0.102 & -0.277 \\
\hline RHO & -0.848 & -0.088 & 0.034 & 0.031 & 0.274 \\
\hline $\mathrm{L}_{\mathrm{o}}$ & -0.063 & -0.119 & 0.986 & 0.056 & 0.041 \\
\hline A & 0.939 & 0.082 & -0.028 & -0.129 & -0.163 \\
\hline $\mathbf{P}$ & 0.918 & 0.078 & -0.062 & -0.313 & -0.068 \\
\hline$R_{f}$ & -0.135 & 0.011 & 0.070 & 0.934 & 0.119 \\
\hline$D_{t}$ & -0.245 & -0.109 & 0.563 & 0.141 & 0.753 \\
\hline $\mathbf{R}_{c}$ & -0.667 & 0.037 & 0.142 & 0.424 & 0.048 \\
\hline $\mathbf{R}_{\mathrm{e}}$ & -0.162 & -0.023 & 0.065 & 0.953 & 0.116 \\
\hline $\mathrm{F}_{\mathrm{s}}$ & -0.270 & -0.092 & 0.240 & 0.140 & 0.886 \\
\hline$D_{d}$ & -0.064 & -0.121 & 0.985 & 0.057 & 0.041 \\
\hline $\mathrm{B}_{\mathrm{s}}$ & 0.225 & 0.070 & -0.032 & -0.885 & -0.053 \\
\hline $\mathrm{C}$ & 0.030 & 0.141 & -0.981 & -0.057 & -0.036 \\
\hline $\mathrm{C}_{\mathrm{c}}$ & 0.770 & 0.018 & -0.097 & -0.486 & 0.044 \\
\hline$B_{h}$ & 0.289 & 0.919 & -0.142 & -0.142 & -0.077 \\
\hline$R_{r}$ & -0.271 & 0.845 & -0.066 & 0.368 & 0.042 \\
\hline $\mathbf{R}_{\mathrm{n}}$ & 0.292 & 0.928 & -0.029 & -0.142 & -0.082 \\
\hline $\mathrm{D}_{\text {is }}$ & 0.246 & 0.934 & -0.181 & -0.064 & -0.063 \\
\hline $\mathbf{M}_{\mathrm{rn}}$ & -0.224 & 0.959 & -0.101 & -0.008 & 0.019 \\
\hline
\end{tabular}

The bold values represent the significant correlation values for each component.

pactness coefficient $(\mathrm{C})$. Thus, the third component reflects the "hydrographic" component. The fourth component exhibits a high positive correlation $(>0.9)$ with the form factor $\left(R_{f}\right)$ and elongation ratio $\left(R_{e}\right)$, consequently, it refers to the sub-watershed "shape component". Principal Component 5 is positively and highly loaded in respect to drainage texture $\left(D_{t}\right)$ and stream frequency $\left(F_{s}\right)$. It is appropriate to label it as the sub-basin "dissection intensity" component.

\subsubsection{Regionalization of Sub-Watersheds: Cluster Analysis}

In the present study we applied CA to classify the 76 sub-watersheds based on the five rotated component scores for each sub-watershed achieved through PCA. Thus, a dendrogram was generated which displays the spatial pattern of regionalization by distinct cluster groups. Ward's method of hierarchical clustering [78] is a frequently used technique for regionalization studies in hydrology, geomorphology, and earth sciences. The clustering procedure is based on the assumption that if two clusters are merged, the resulting loss of information, or change in the value of objective function, will depend on the relationship between the merged clusters and not on the relationships with any other clusters. 
The results of this procedure is a set of homogeneous sub-watersheds in terms of their measured "differentiating characteristics". According to this hierarchical method, clusters are formed by iterative fusion of sub-basin with sub-basin, sub-basin with cluster or, cluster with cluster at successively higher levels of dissimilarity. The resultant clusters and sub-clusters are illustrated in a dendrogram [79] [80]. Ward's method is considered a minimum variance technique. It generates taxonomic classes with a minimized overall distribution of attributes. At any stage of grouping the "loss of information" (or the objective function) which results from the grouping of sub-basins (individuals) into clusters can be measured by the sum total of Squares (ESS) combined [78]. Cluster Analysis was effective in the regionalizing of sub-watersheds based on the coefficient of similarity into five different clusters (level I of clustering), and two clusters (level II of clustering) (Figure 8). With reference to the PCs scores (or factor scores), 38

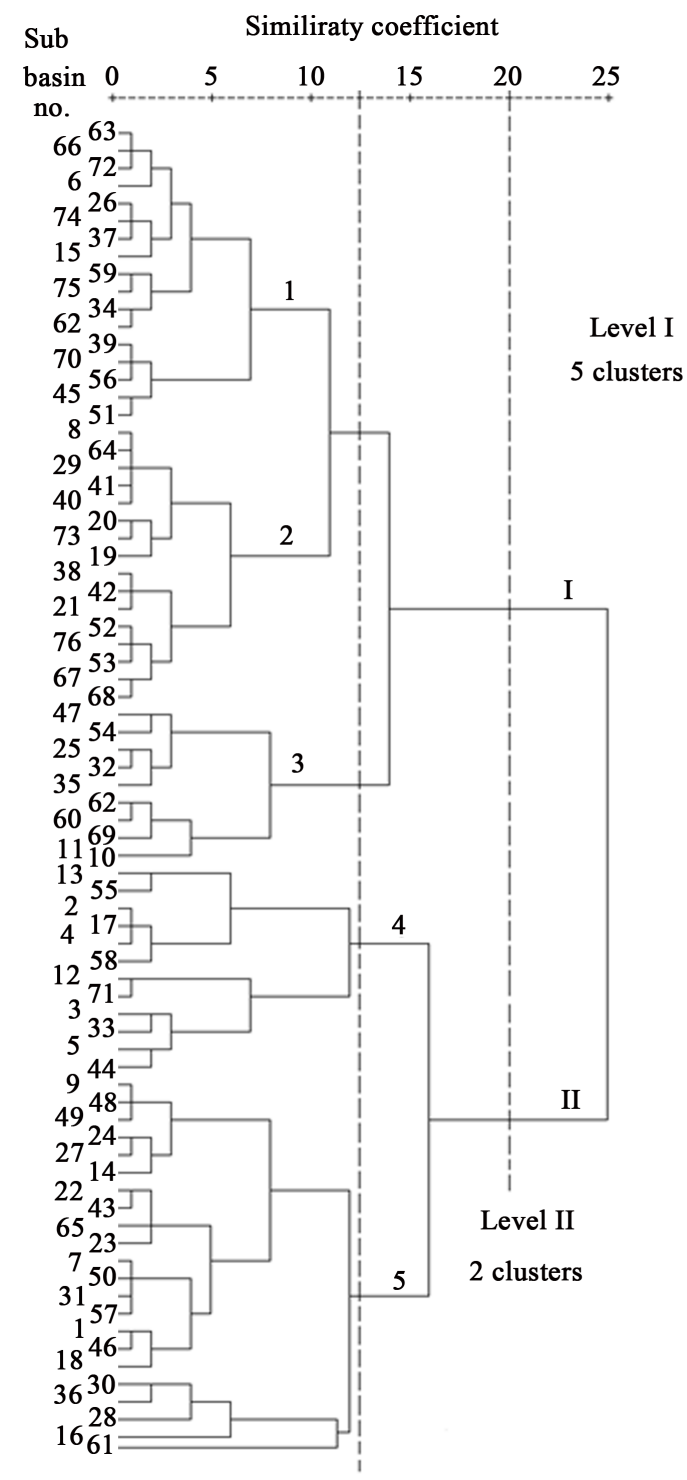

Figure 8. Two levels of clustering: level (I) produced five clusters, and level (II) resulted in two clusters. 
sub-watersheds (50\% of the total) are of high positive loadings $(>0.6)$ on $\mathrm{PC}_{1}$ and $\mathrm{PC}_{3}$, while the remaining sub-watersheds are also highly loaded $(>0.6)$ on $\mathrm{PC}_{2}$, $\mathrm{PC}_{4}$, and $\mathrm{PC}_{5}$. In general, a major cluster (2) of level II of clustering, accommodates the minor clusters 4 and 5, representing in a remarkable way the rejuvenation belt characterizing central Jordan [43] [62] [81]. Whereas, the major cluster (1) which relates to level II of clustering is subdivided into clusters 1,2 and 3 and occupies the eastern section of the watershed (Figure 8), which is less influenced by recent tectonic activity and deep incision. Clusters 4 and 5 (level I of clustering) represent sub-basins which are significantly affected by rejuvenation processes. Figure 9 illustrates the spatial distribution of the two clusters (two sub-basin regions) which represent sub-basins of the rejuvenated belt and, subbasins of the eastern zone of W. Mujib-Wala watershed. Similarly, Figure 10

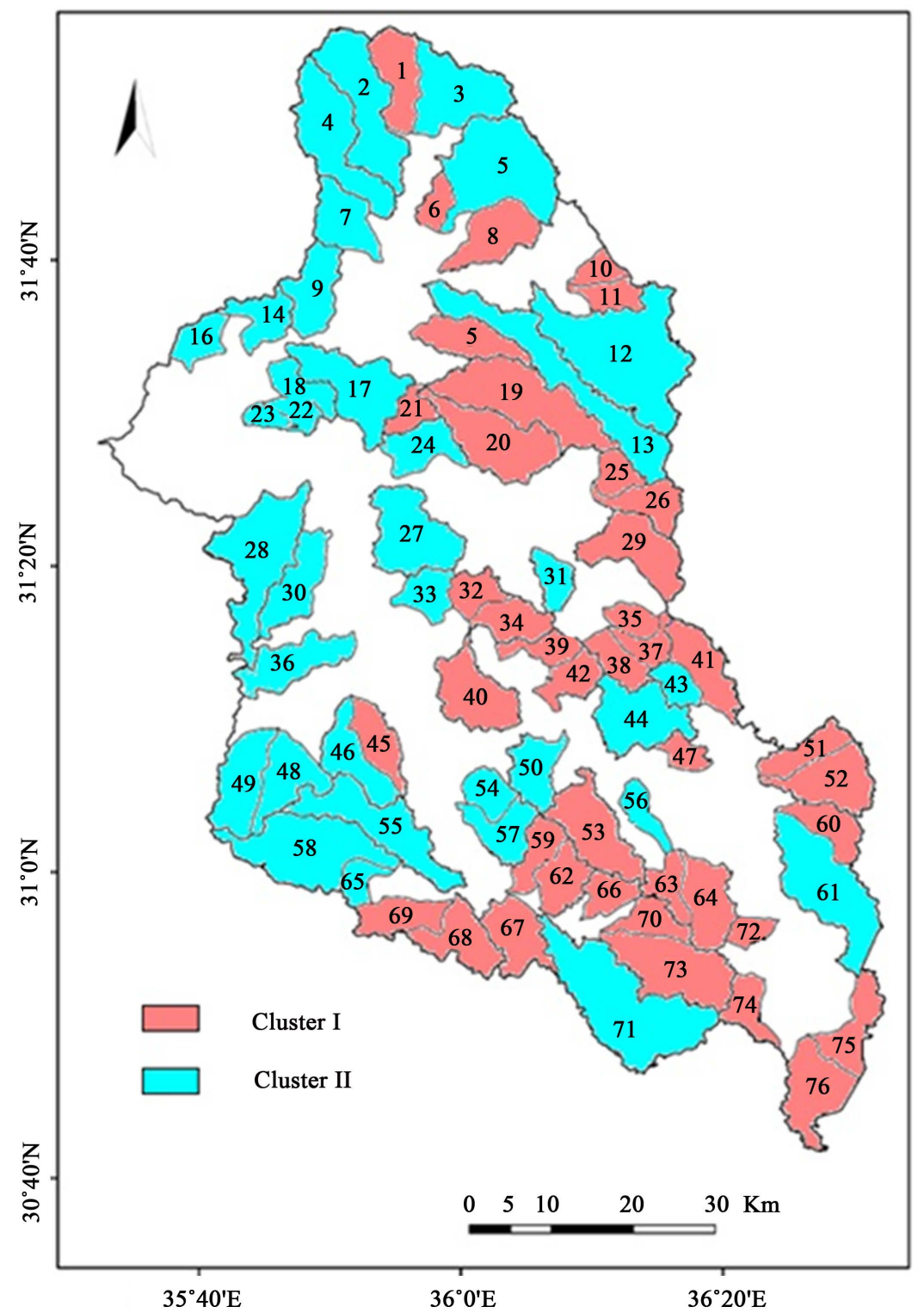

Figure 9. Spatial distribution of the two homogeneous regions of sub-basins using component loads. 
displays the spatial distribution of the five clusters, or five regions which refer to the sub-basins of the rejuvenated belt and the transitional sub-basins between the rejuvenated belt and the eastern zone. All the 76 sub-basins are at the youth-stage of geomorphic development as demonstrated by their hypsometric curves (HC) and hypsometric integral (HI) values [43]. However, noticeable differences exist among the 76 sub-watersheds due to variation in lithology, structure and tectonic activity, and rejuvenation. The cluster 2 of level II is heavily influenced by intense progressive subsidence of the Dead Sea base level (the lowest base level in the Jordan Rift and worldwide) which was the main factor creating the high rate of Pliocene/Pleistocene fluvial erosion along the lower reaches

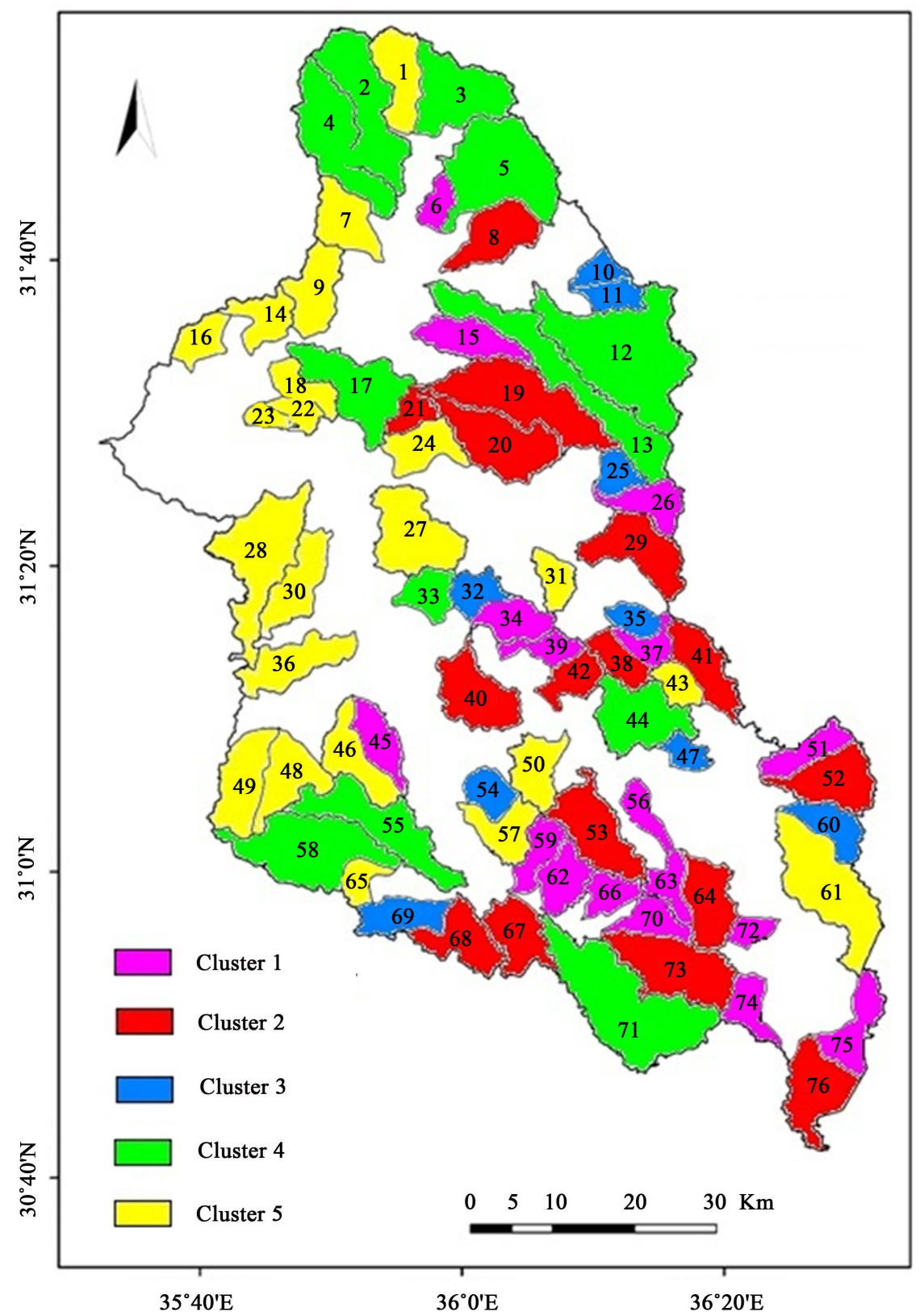

Figure 10. Clustering of sub-watersheds into five regions of sub-basins using component loads. 
of the W. Wadi Mujib-Wala catchment [63]. Thus, a high magnitude rejuvenation phases affects the entire watershed and the related sub-basins. Rejuvenation processes produced severe incision, deeply dissected terrain, active hill-slope processes, over steepened and interrupted slopes, high sediment yields and high soil erosion rates, repetitive flooding, and the development of a deep canyon landscape [43]. Relative variation in morphometric properties also exists among the 76 sub-watersheds as exemplified by the hypsometric integral (HI) and basin relief $\left(B_{h}\right)$ values. It was stated earlier, that the HI values decrease from $>0.85$ characterizing the western sub-basins, to $0.80-0.85$ in the middle and southern part of the catchment. A third category of HI values $(0.70-0.80)$ is restricted to the sub-watersheds located adjacent the northeastern, eastern, and southern margins of W. Mujib-Wala catchment. High values of $\mathrm{HI}$ are probably attributed to young active tectonics: uplifting, subsidence and downfaulting, and progressive lowering of the Dead Sea base level, and successive rejuvenation. Lower values of HI characterized sub-basins located at the eastern margins of the watershed indicating that these sub-basins areas are less impacted by tectonic activity, stream incision and headward erosion. The remnants of the Arabia Surface (the Oligocene peneplain) still stand adjacent to the southern and northern shoulders of W. Mujib-Wala watershed. Clusters 1, 2, and 3 (level I of clustering) are influenced during their evolution by local structures affecting the entire catchment such as: the Zerqa Ma'in fault system (E-W direction), the Shihan-Swaqa fault system (E-W direction), and the NW-SE Kerak Al-Fiha fault system Thus, the impact of physical factors (structure and lithology, geomorphic development, rejuvenation, fluvial erosion, and slope processes) on clustering was noticeable in each sub-basin group. Furthermore, the basin relief $\left(B_{h}\right)$ values for the 76 sub-watersheds are high and vary from $93 \mathrm{~m}$ to $880 \mathrm{~m}$, thus, the relief ratio $\left(\mathrm{R}_{\mathrm{r}}\right)$ and ruggedness number $\left(\mathrm{R}_{\mathrm{n}}\right)$ values are high as well, which denote the predominance of high erosion energy and slope processes (i.e., high soil loss, high sediment yield, and landslide activity) among these sub-basins. Rapid decline of the Dead Sea level is an ongoing process at a rate exceeding $0.50 \mathrm{~m}$ annually [82]. Based on the results of headward incision rates found by Hassan and Klien [82] on the River Jordan, it can claimed that headward incision by main channels of W.Mujib-Wala is in progress at present, especially in soft rock units. Such a conclusion is substantiated by field observations [18] [19].

\subsubsection{Validation of Regionalization: Discriminant Analysis}

The validity of regionalization of the 76 sub-basins determined through CA: the cluster groups (1 - 5) (level I of clustering), and the other two clusters (level II of clustering) of sub-basins (Figure 8), was tested using DA. It is intended in this context to test the hypothesis that there is a significant differences between the cluster groups found earlier, and if this hypothesis is accepted, to establish a system of coordinate axis which discriminates between the identified five clusters or regions of sub-watersheds. With reference to the five groups of clustering (Figure 11), it is apparent that there is a significant difference between the clusters $1-5$, with a noticeable concentration of groups 1-3 in the eastern and southern 


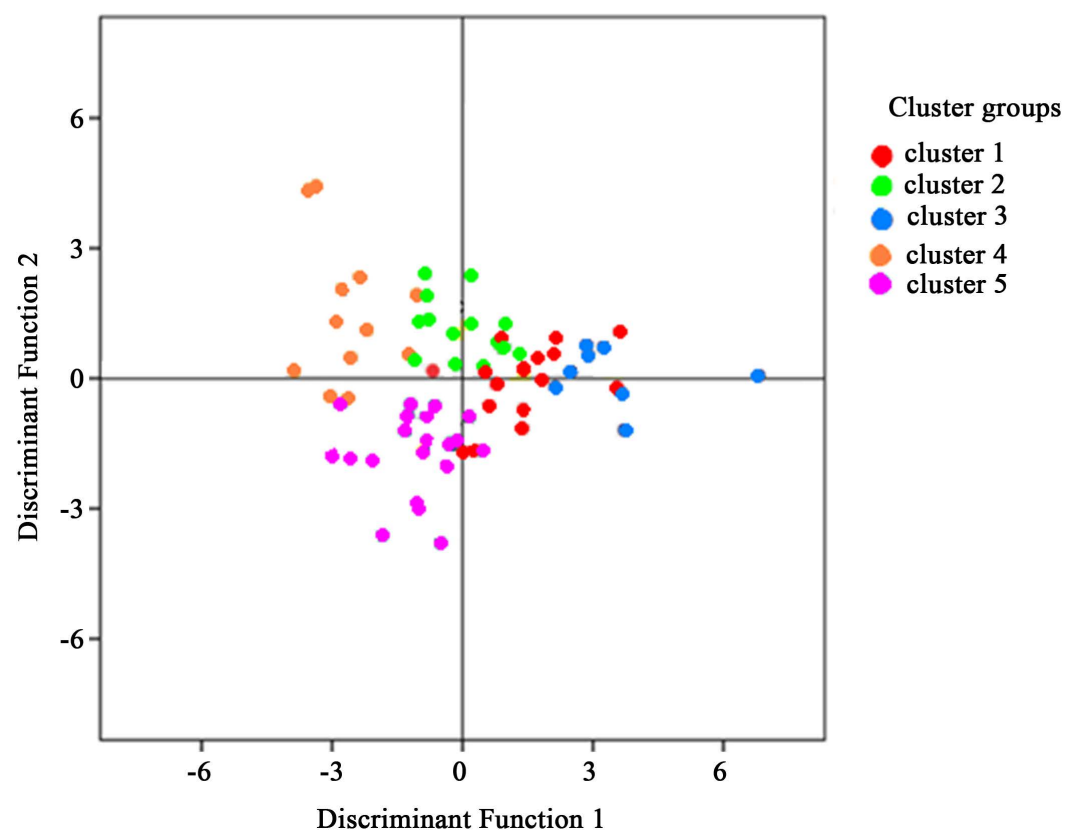

Figure 11. Results of discriminant functions 1 and 2 grouping: the five clusters are relatively separated.

parts of W. Mujib-Wala watershed, and groups 4 and 5 in the western part of the catchment. The F test of Wilks Lambda obtained is: F ratio is 28.4, with degrees of freedom V1 $=4$ and $\mathrm{V} 2=71$. Referring to a table of percentage points of the F-distribution, with V1 $=4$ and V2 $=71$, it was found that at 99 percent of confidence, the tabulated values is 3.48 , which is significantly exceeded by the computed $\mathrm{F}$ ratio value (28.4). Consequently, there is a highly significant difference between each of the groups 1-5. The five groups of sub-basins are reasonably distinct (Figure 10). Furthermore, 96.7 percent of the difference between the groups is attributed to Discriminant function No. 1 (66.9 percent) and Discriminant function No.2 (29.7 percent).Whereas the third Discriminant function contributed only 3.3 percent. It also revealed that the major contributor tothe first $\mathrm{LDF}$ is the $\mathrm{PC}_{3}$ or the "hydrographic" component $\left(\mathrm{L}_{\mathrm{o}}, \mathrm{D}_{\mathrm{d}}\right.$, and $\left.\mathrm{C}\right)$, whereas $\mathrm{PC}_{5}$, or the "dissection intensity" component $\left(\mathrm{D}_{\mathrm{t}}\right.$ and $\left.\mathrm{F}_{\mathrm{s}}\right)$ contributes most to the second LDF. These results confirm the discussion regarding the spatial distribution of sub-basin groups 1-5, where the two cluster groups (4 and 5) represent sub-basins remarkably influenced by rejuvenation processes, uplifting, and tilting characterizing central Jordan [43] [62] [81]. By contrast, the other three cluster groups 1 - 3 are restricted to the eastern zone of W. Muji-Wala watershed which is less influenced by deep incision and recent tectonic activity, therefore, it is less impacted by rejuvenation. The scores of each sub-basin of the five groups on the Discriminant functions 1 and 2, were plotted on Figure 11. The plot displays well separated clusters, with slight overlapping between the groups. Furthermore, DA was also applied on the two major sub-basin cluster (1 and 2) of the second level of clustering (Figure 8). The first group consists of 42 sub-basins located at the eastern part of the watershed, while group 2 is composed of 34 
sub-basins and is located at the western part of the catchment. The results showed that the two major groups are significantly different from one another although a complete separation between the two groups is not realized. The overlapped area accommodates relatively uniform sub-basins representing a transitional zone between the rejuvenated belt in the west, and the eastern sector of the watershed. The F test of Wilks Lambda obtained indicates: the F ratio is 7.1 with V1 $=15$ and V2 is 20006 . The computed value from the F-distribution tables at 99 percent confidence is 2061 . The latter value is again substantially exceeded by the F ratio value (7.1). Subsequently, these findings indicate that there is significant difference between group (1) of sub-basins representing the eastern zone of W. Mujib-Wala watershed, and group (2) of sub-basins which belongs to the rejuvenated belt. Nevertheless, incomplete separation indicates that the regions of sub-basins identified by clustering are in general not completely homogeneous. Such results could not reduce the value of the determined sub-basins regions, since the criteria of overlapping and boundary intersection are familiar in regionalization studies, including hydrological classification of watersheds based on multivariate statistical techniques [20] [53] [83].

\section{Conclusions}

Results from this investigation showed the significant roles of morphometric analysis, GIS, and multivariate statistics in hydrological regionalization of 76 sub-watersheds of which W. Mujib-Wala is composed. Twenty-two morphometric parameters related to the entire catchment and the associated sub-basins were extracted using ASTER DEM, and subjected to Principal Component Analysis, Cluster Analysis, and Discriminant Analysis. PCA resulted in five major components that account for $90.4 \%$ of the total variance explained by the 22 morphometric variables. It is apparent that the first three PCs (PC1-PC3) account for $63.93 \%$ of the total variance proportion of input parameters. It is obvious that parameters such as $\mathrm{Nu}, \mathrm{L}_{\mathrm{u}}, \mathrm{R}_{\mathrm{bm}}, \mathrm{A}, \mathrm{P}$ and $\mathrm{C}$ have the greatest input parameter variance proportions (28.6\%), and the most effect on the first component. Thus, it is labled as "sub-watershed size". Furthermore, $B_{h}, R_{r}, R_{n}, D_{i s}$, and $\mathrm{M}_{\mathrm{rn}}$ parameters have the most effect on the second component, which comprises $19.61 \%$ of input variance proportions. Therefore, it is appropriate to label it as the "slope steepness and relief" component. $\mathrm{PC}_{3}$ is affected by $\mathrm{L}_{0}, \mathrm{D}_{\mathrm{d}}$, and $\mathrm{C}$, and accounts for $15.73 \%$ of input variance proportions. Accordingly, $\mathrm{PC}_{3}$ is termed as the "hydrographic" component. Parameters such as $R_{f}, R_{e}$ have the most effect on $\mathrm{PC}_{4}$, thus, it refers to the "sub-watershed shape" component, whereas parameters such as $\mathrm{D}_{\mathrm{t}}$, and $\mathrm{F}_{\mathrm{s}}$ have the most impress on $\mathrm{PC}_{5}$, which is labeled as the sub-basin "dissection intensity" component. Based on the five rotated components, Cluster Analysis (CA) allows the 76 sub-watersheds to be classified in five groups.

The generated cluster dendrogram (and the maps produced) clearly display the spatial pattern of sub-basin groups or regions. At the first level of clustering, five separate cluster groups were demarcated, whereas at the second level of 
clustering, two major groups ( 1 and 2 ) of sub-watersheds were derived. The major group (2) of level II of clustering noticeably represents the rejuvenation belt. Sub-basins of major cluster (2) are strongly affected by rejuvenation stages, uplifting, fluvial erosion and severe incision, and hillslope processes. By contrast, sub-basins of major cluster (1) occupying the eastern section of W. Mujib-Wala watershed, are less influenced by rejuvenation and deep incision. All the subwatersheds are at the youth-stage of geomorphic development as demonstrated by their hypsometric curves and high $\mathrm{HI}$ values. $\mathrm{HI}$ values decrease from $>0.85$ which characterize the rejuvenated belt sub-basins, to $0.70-0.80$ which characterize sub-basins located at the eastern part of W. Mujib-Wala watershed.

The validity of sub-watersheds regionalization was tested statistically using Discriminant Analysis. With reference to the five groups of clustering (or regions of sub-basins), it is found that there is a significant difference between clusters 1 - 5 (at 99 percent of confidence), thus these regions are reasonably distinct. Consequently, they are vary in their morphometric properties and hydrological characteristics. The major contributor to the first $\mathrm{LDF}$ is the $\mathrm{PC}_{3}$ or the "hydrographic" component. Whereas $\mathrm{PC}_{5}$, or the "dissection intensity" component contributes most to the second LDF. Moreover, a significant difference exists between the major group (1) of sub-basins which represents the eastern zone of W. Mujib-Wala watershed, and the major group (2) representing the rejuvenated belt.

The findings obtained above reveal that W. Mujib-Wala watershed is divided by clustering from west to east into five groups of sub-basins, and two major groups of sub-watersheds were identified. Two groups of the five represent subbasins influenced heavily by rejuvenation processes and tectonics, whereas the other three groups occupy the eastern zone of the watershed which is less impacted by rejuvenation and tectonic activity. However, the two major groups are consistent with the regional geomorphic development of central Jordan, morphometric properties of the 76 sub-basins, and with regional precipitation patterns decreasing from west to east, along the watershed. Sub-watershed regionalization based on geomorphometric characteristics provides efficient information for modeling the hydrological responses, i.e., surface runoff and sediment yield from W. Mujib-Wala catchment, and the 76 sub-basins. Furthermore, such information is useful for hydrological assessment of the catchment in light of the shortage of available water resources, and expanding human activities (i.e., dam construction, agriculture and urbanization) which can exacerbate flooding and drought hazards over the watershed. Regionalization process can be a useful tool to support water resources planning and management in relation to domestic utilization, expansion of irrigated agriculture and artificial recharge of groundwater.

\section{References}

[1] Bender, F. (1975) Geology of the Arabian Peninsula: Jordan. United States Geological Survey Professional Paper 560-I, Washington DC. 
[2] Horton, R. (1945) Erosional Development of Streams and their Drainage Basins; Hydrophysical Approach to Quantitative Morphology. Geological Society of America Bulletin, 56, 275-370. https://doi.org/10.1130/0016-7606(1945)56[275:EDOSAT]2.0.CO;2

[3] Strahler, A.N. (1952) Dynamic Basis of Geomorphology. Geological Society of America Bulletin, 63, 923-938. https://doi.org/10.1130/0016-7606(1952)63[923:DBOG]2.0.CO;2

[4] Strahler, A.N. (1957) Quantitative Analysis of Watershed Geomorphology. Transactions, American Geophysical Union, 138, 913-938. https://doi.org/10.1029/TR038i006p00913

[5] Strahler, A.N. (1964) Quantitative Geomorphology of Drainage Basins and Channel Networks. In: Chow, V.T, Ed., Handbook of Applied Hydrology, McGraw-Hill, New York, 4-39-4-76.

[6] Smith, K. (1950) Standards for Grading Textures of Erosional Topography. American Journal of Science, 248, 655-668. https://doi.org/10.2475/ajs.248.9.655

[7] Miller, V. (1953) A Quantitative Geomorphic Study of Drainage Basin Characteristics in the Clinch Mountain Area, Virginia and Tennessee. Project NR 389-402, Technical Report 3, Columbia University, New York.

[8] Schumm, S. (1956) Evolution of Drainage Systems and Slopes in Badlands at Perth Amboy, New Jersey. Geological Society of America Bulletin, 64, 597-646. https://doi.org/10.1130/0016-7606(1956)67[597:EODSAS]2.0.CO;2

[9] Lifton, N.A. and Chase, C.G. (1992) Tectonic, Climatic and Lithologic Influences on Landscape Fractal Dimension and Hypsometry: Implications for Landscape Evolution in the San Gabriel Mountains, California. Geomorphology, 45, 77-114.

[10] Ohmori, H. (1993) Changes in the Hypsometric Curve through Mountain Building Resulting from Concurrent Tectonics and Denudation. Geomorphology, 8, 263-277.

[11] Weissel, J., Pratson, L. and Malinverno, A. (1994) The Length-Scaling Properties of Topography. Journal of Geophysical Research, 99, 13997-14012. https://doi.org/10.1029/94JB00130

[12] Hurtrez, J.E., Sol, C. and Lucazeau, F. (1999) Effect of Drainage Area on Hypsometry Form Analysis of Small Scale Drainage Basins in the Siwalik Hills (Central Nepal). Earth Surface Processes and Landforms, 24, 799-808. https://doi.org/10.1002/(SICI)1096-9837(199908)24:9<799::AID-ESP12>3.0.CO;2-4

[13] Singh, T. (2003) Hypsometric Analysis of Watersheds Developed on Actively Deforming Mohand Ancticlinal Ridge, NW Himalaya. Geocarto International, 23, 417-427. https://doi.org/10.1080/10106040801965821

[14] Markose, V.J. and Jayappa, K.S. (2011) Hypsometric Analysis of Kali River Basin, Karnataka, India, Using Geographical Information System. Geocarto International, 26, 553-568. https://doi.org/10.1080/10106049.2011.608438

[15] Kusre, B.C. (2013) Hypsometric Analysis and Watershed Management of Diyung Watershed in North Eastern India. Journal of Geological Society of India, 82, 262270. https://doi.org/10.1007/s12594-013-0148-x

[16] Siddiqui, S. and Soldati, M. (2013) Appraisal of Active Tectonics Using Dem-Based Hypsometric Integral and Trend Surface Analysis in Emilia-Romagna Apennines, Northern Italy. Turkish Journal of Earth Sciences, 23, 277-292. https://doi.org/10.3906/yer-1306-12

[17] Yunus, A.P. (2016) Geomorphic and Lithologic Control on Bedrock Channels in Drainage Basins of the Western Arabian Peninsula. Arab Journal of Geosciences, 9, 133-146. https://doi.org/10.1007/s12517-015-2179-7 
[18] Farhan, Y., Elgaziri, A., Elmaji, I. and Ali, I. (2016a) Hypsometric Analysis of Wadi Mujib-Wala Watershed (Southern Jordan) Using Remote Sensing and GIS Techniques. International Journal of Geosciences, 7, 158-176.

https://doi.org/10.4236/ijg.2016.72013

[19] Farhan, U., Mousa, R., Dagarah, A. and Shtaya, D. (2016b) Regional Hypsometric Analysis of the Jordan Rift Drainage Basins (Jordan) Using Geographic Information System. Open Journal of Geology, 6, 1312-1343. https://doi.org/10.4236/ojg.2016.610096

[20] Mather, P. and Doornkamp, J.C. (1970) Multivariate Analysis in Geography with Particular Reference to Drainage-Basin Morphometry. Transactions of the Institute of British Geographers, 51, 163-187. https://doi.org/10.2307/621768

[21] Mather, P. (1986) Computational Methods and Multivariate Analysis in Physical Geography. Wiley, London.

[22] Gradiner, V. (1978) Redundancy and Spatial Organization of Drainage Basin Form Indices: An Empirical Investigation of Data from North-West Devon. Transactions of the Institute of British Geographers, 3, 416-431. https://doi.org/10.2307/622121

[23] Marcos, A. (1980) First-Order Drainage Basin Morphology-Definition and Distribution. Earth Surface Processes and Landforms, 5, 389-398. https://doi.org/10.1002/esp.3760050408

[24] Parsons, A.J. (1980) Slope Profile Variability in First-Order Drainage Basins. Earth Surface Processes and Landforms, 5, 71-78. https://doi.org/10.1002/esp.3290070109

[25] Subyani, A.M., Qari, M.H. and Mastah, M.A. (2012) Digital Elevation Model and Multivariate Statistical Analysis of Morphometric Parameters of Some Wadis, Western Saudi Arabia. Arab Journal of Geosciences, 5, 147-157. https://doi.org/10.1007/s12517-010-0149-7

[26] Raux, J., Copard, Y., Laignel, B., Fournier, M. and Massei, N. (2011) Classification of Worldwide Drainage Basins through the Multivariate Analysis of Variables Controlling Their Hydro-Sedimentary Response. Global and Planetary Change, 73, 117 127.

[27] Ghimire, M. (2014) Multivariate Morphological Characteristics and Classification of First-Order Basins in the Siwaliks, Nepal. Geomorphology, 204, 192-207.

[28] Yunus, A., Oguchi, T. and Hayakawa, U. (2014) Morphometric Analysis of Drainage Basins in the Western Arabian Peninsula Using Multivariate Statistics. International Journal of Geosciences, 5, 527-539. https://doi.org/10.4236/ijg.2014.55049

[29] Sharma, S.K., Gajbhiye, S. and Tignath, S. (2015) Application of Principal Component Analysis in Grouping Parameters for Hydrological Modeling. Applied Water Science, 5, 89-96. https://doi.org/10.1007/s13201-014-0170-1

[30] Farhan, Y., Anbar, A., Enaba, O. and Al-Shaikh, N. (2015) Quantitative Analysis of Geomorphometric Parameters of Wadi Kerak, Jordan, Using Remote Sensing and GIS. Journal of Water Resources and Protection, 7, 456-475. https://doi.org/10.4236/jwarp.2015.76037

[31] Youssef, A., Pradhan, B. and Sefry, S. (2016) Flash Flood Susceptibility Assessment in Jedda City (Kingdom of Saudi Arabia) Using Bivariate and Multivariate Statistical Models. Environmental Earth Sciences, 75, 1-16. https://doi.org/10.1007/s12665-015-4830-8

[32] Biswas, S., Sudhakar, S. and Desai, V. (1999) Prioritization of Sub-Watersheds Based on Morphometric Analysis of Drainage Basin: A Remote Sensing and GIS Approach. Journal of the Indian Society of Remote Sensing, 27, 155-166. https://doi.org/10.1007/BF02991569 
[33] Nooka Ratnam, K., Srivastava, Y.K., Venkateshwara Rao, V., Amminedu, E. and Murthy, K.S.R. (2005) Check Dam Positioning and Prioritization of Micro-Watersheds Using SYI Model and Morphometric Analysis-Remote Sensing and GIS Perspective. Journal of the Indian Society of Remote Sensing, 33, 25-38. https://doi.org/10.1007/BF02989988

[34] Patel, D., Gajjar, C. and Srivastava, P. (2013) Prioritization of Malesari Mini-Watersheds through Morphometric Analysis: A Remote Sensing and GIS Perspective. Environmental Earth Sciences, 69, 2643-2656. https://doi.org/10.1007/s12665-012-2086-0

[35] Potter, K.W. and Frevert, D.K. (2010) Innovation in Watershed Management under Land Use and Climate Change. Proceedings of the 2010 Watershed Management Conference, Madison, 23-27 August 2010. https://doi.org/10.1061/9780784411438

[36] Youssef, A., Pradhan, B. and Green, D. (2011) Risk Estimation along the St. Katherine Road, Southern Sinai, Egypt Using GIS Based Morphometry and Satellite Imagery. Environmental Earth Sciences, 62, 611-623. https://doi.org/10.1007/s12665-010-0551-1

[37] El-Shamey, I. (1992) Recent Recharge and Flash Flooding Opportunities in the Eastern Desert, Egypt. Annals of the Geological Survey of Egypt, 18, 323-334.

[38] Abdel-Lattif, A. and Sherief, Y. (2012) Morphometric Analysis of Flash Floods of Wadi Sudr and Wadi Wardan, Gulf of Suez, Egypt: Using Digital Elevation Model. Arab Journal of Geosciences, 5, 181-195. https://doi.org/10.1007/s12517-010-0156-8

[39] Khandy, M. and Javed, A. (2016) Prioritization of Sub-Watersheds for Conservation Measures in a Semi Arid Watershed Using Remote Sensing and GIS. Journal of the Geological Society of India, 88, 185-196. https://doi.org/10.1007/s12594-016-0477-7

[40] Makwana, J. and Tiwari, M. (2016) Prioritization of Agricultural Sub-Watershed in Semi-Arid Middle Region of Gujarat Using Remote Sensing and GIS. Environmental Earth Sciences, 75, 137. https://doi.org/10.1007/s12665-015-4935-0

[41] Gopinath, G., Nair, A., Ambili, G. and Swetha, T. (2016) Watershed Prioritization Based on Morphometric Analysis Coupled with Multi Criteria Decision Making. Arab Journal of Geosciences, 9, 129-146. https://doi.org/10.1007/s12517-015-2238-0

[42] Fallah, M., Kavian, A. and Omidver, E. (2016) Watershed Prioritization in Order to Implement Soil and Water Conservation Practices. Environmental Earth Sciences, 75, 1248-1265. https://doi.org/10.1007/s12665-016-6035-1

[43] Farhan, Y. and Anaba, O. (2016a) A Remote Sensing and GIS Approach for Prioritization of Wadi Shueib Mini Watersheds (Central Jordan) Based on Morphometric and Soil Erosion Susceptibility Analysis. Journal of Geographic Information System, 8, 1-19. https://doi.org/10.4236/jgis.2016.81001

[44] Farhan, Y. and Anaba, O. (2016b) Watershed Prioritization Based on Morphometric Analysis and Soil Loss Modeling in Wadi Kerak (Southern Jordan) Using GIS Techniques. International Journal of Plant \& Soil Science, 10, 1-18. https://doi.org/10.9734/IJPSS/2016/25321

[45] Pareta, K. and Pareta, U. (2011) Quantitative Morphometric Analysis of a Watershed of Yamuna Basin, India Using ASTER (DEM) Data and GIS. International Journal of Geomatics and Geosciences, 2, 248-269.

[46] Miller, J.R., Ritter, D.F. and Kochel, R.C. (1990) Morphometric Assessment of Lithologic Controls on Drainage Basin Evolution in the Crawford Uplands, SouthCentral Indiana. American Journal of Science, 290, 569-599. https://doi.org/10.2475/ajs.290.5.569

[47] Bothale, R.V., Bothale, V.M. and Sharma, J.R. (1998) Delineation of ECO Water- 
sheds by Integration of Remote Sensing and GIS Techniques for Management of Water and Land Resources. In: Fritsch, D., English, M. and Sester, M., Eds., IAPRS, ISPRS-Commission IV Symposium on GIS between Visions and Applications, Vol. 32/4, Stuttgart.

[48] Frissel, C. Liss, W., Warren, C. and Hurley, M. (1986) A Hierarchical Framework for Stream Habitat Classification: Viewing Streams in a Watershed Context. Environmental Management, 10, 199-2014. https://doi.org/10.1007/BF01867358

[49] Bengraine, K. and Marhaba, T.F. (2003) Using Principal Component Analysis to Monitor Spatial and Temporal Changes in Water Quality. Journal of Hazardous Materials, 100, 179-195.

[50] Lins, H.F. (1985) Interannual Stream Flow Variability in the United States Based on Principal Components. Water Resources Research, 21, 691-701. https://doi.org/10.1029/WR021i005p00691

[51] Hannachi, A., Jolliffe, I.T. and Stephenson, D.B. (2007) Empirical Orthogonal Functions and Related Techniques in Atmospheric Science: A Review. International Journal of Climatology, 27, 1119-1152. https://doi.org/10.1002/joc.1499

[52] Belmar, O., Velasco, J. and Martinez-Capetl, F. (2011) Hydrological Classification of Natural Flow Regimes to Support Environmental Flow Assessments in Intensively Regulated Mediterranean Rivers, Segura River Basin (Spain). Environmental Management, 47, 992-1004. https://doi.org/10.1007/s00267-011-9661-0

[53] Frasadnia, F., Kamrood, M.R., Nia, A.M., Modarres, R., Bray, M.T., Han, D. and Sadatinejad, J. (2014) Identification of Homogeneous Regions for Regionalization of Watersheds by Two-Level Self-Organizing Feature Maps. Journal of Hydrology, 509, 387-397.

[54] Chiang, S., Tsay, T. and Nix, S.J. (2002) Hydrologic Regionalization of Watersheds. I: Methodology Development. Journal of Water Resources Planning and Management, 128, 3-11. https://doi.org/10.1061/(ASCE)0733-9496(2002)128:1(3)

[55] Mehaiguene, M., Meddi, M., Longobardi, A. and Toumi, S. (2012) Low Flows Quantification and Regionalization in North West Algeria. Journal of Arid Environments, 87, 67-76.

[56] Chuman, T. and Ramportl, D. (2010) Multivariate Classification Analysis of Cultural Landscapes: An Example from the Czech Republic. Landscape and Urban Planning, 98, 2000-2009.

[57] Peterson, H.M., Nieber, J.L. and Kanivetsky, R. (2011) Hydrologic Regionalization to Assess Anthropogenic Changes, Journal of Hydrology, 408, 212-225.

[58] Dinpashoh, Y., Fakheri-Frad, A., Moghaddam, M., Jahanbakhsh, S. and Mirnia, M. (2004) Selection of Variables for the Purpose of Regionalization of Iran's Precipitation Climate Using Multivariate Methods. Journal of Hydrology, 297, 109-123.

[59] Abdel-Hamid, M., El Tahan, H. and Elhanaty, H.M. (2016) Statistical Analysis of Morphometric and Hydrologic Parameters in Arid Regions, Case Study of Wadi Hadramaut. Arab Journal of Geosciences, 9, 88. https://doi.org/10.1007/s12517-015-2195-7

[60] Ijam, A. and Tarawneh, E. (2012) Assessing of Sediment Yield for Wala Dam Catchment Area in Jordan. European Water, 38, 43-58.

[61] Ijam, A. and Al-Mahamid, M. (2012) Predicting Sedimentation at Mujib Dam Reservoir in Jordan. Jordan Journal of Civil Engineering, 6, 448-463.

[62] Burdon, D. (1959) Handbook of the Geology of Jordan. Benham and Co., Colchester.

[63] De Jaegar, C. and de Dapper, M. (2002) Tectonic Control in the Geomorphic De- 
velopment of the Wadi el-Mujib Canyon (Jordan) EGU. Stephan Mueller Special Publication Series, 2, 83-94. https://doi.org/10.5194/smsps-2-83-2002

[64] Kanth, T. and Hassan, Z. (2012) Morphometric Analysis and Prioritization of Watersheds for Soil and Water Resources Management in Wular Catchment Using Geo-Spatial Tools. International Journal of Geology, Earth and Environmental Sciences, $2,30-41$.

[65] Magesh, N.S., Chandrasekar, N. and Soundranayagam, J.P. (2011) Morphometric Evaluation of Papanasam and Manimuthar Watersheds, Part of the Western Ghats. Tirunelveli Distric, Tamil Nadu, India: A GIS Approach. Environmental Earth Sciences, 64, 373-381. https://doi.org/10.1007/s12665-010-0860-4

[66] Zavoianu, I. (1985) Morphometry of Drainage Basins (Developments in Water Science). Elsevier, Amsterdam.

[67] Sreedevi, P., Sreekanth, P., Khan, H. and Ahmed, S. (2013) Drainage Morphometry and its Influence on Hydrology in a Semi Arid Region: Using SRTM Data and GIS. Environmental Earth Sciences, 70, 839-848. https://doi.org/10.1007/s12665-012-2172-3

[68] Langbein, W.B. (1947) Topographic Characteristics of Drainage Basins. USGS Water Supply Paper, 947-C, 157 p.

[69] Prasad, R., Mondal, N., Banerjee, P., Nandakumar, M. and Singh, V. (2008) Deciphering Potential Groundwater Zone in Hard Rock through the Application of GIS. Environmental Geology, 55, 467-475. https://doi.org/10.1007/s00254-007-0992-3

[70] Deju, R. (1971) Regional Hydrology Fundamentals. Gordon and Breach Science Publishers, Newark.

[71] Masoud, M.H. (2016) Geoinformatics Application for Assessing the Morphometric Characteristics' Effect on Hydrological Response at Watershed (Case Study of Wadi Qanuah, Saudi Arabia). Arab Journal of Geosciences, 9. https://doi.org/10.1007/S12517-015-2300-Y

[72] Rais, S. and Javed, A. (2014) Identification of Artificial Recharge Sites in Manchi Basin, Eastern Rajasthan (India) Using Remote Sensing and GIS Techniques. Journal of Geographic Information System, 6, 162-175. https://doi.org/10.4236/jgis.2014.62017

[73] Vieceli, N., Bortolin, T.A., Mendes, L.A., Bacarim, G., Cemin, G. and Schneider, V.E. (2015) Morphometric Evaluation of Watersheds in Caxias do Sul City, Brazil, Using SRTM (DEM) Data and GIS. Environmental Earth Sciences, 73, 5677-5685. https://doi.org/10.1007/s12665-014-3823-3

[74] Gravelius, H. (1914) Grundriß der gesamten Gewässerkunde, Band 1: Flußkunde. Compendium of Hydrology, I, 265-278.

[75] Patton, P. and Baker, V. (1976) Morphometry and Floods in Small Drainage Basin Subject of Diverse Hydrogeomorphic Controls. Water Resources Research, 12, 441952. https://doi.org/10.1029/WR012i005p00941

[76] Milton, M.A. (1965) The Geomorphic and Paleo Climatic Significance of Alluvial Deposits in Southern Arizona. Journal of Geology, 73, 1-38. https://doi.org/10.1086/627044

[77] Wilford, D.J., Sakals, M.E., Innes, J.L., Sidle, R.C. and Bergerud, W.A. (2004) Recognition of Debris Flow, Debris Flood and Flood Hazard through Watershed Morphometrics. Landslides, 1, 61-66. https://doi.org/10.1007/s10346-003-0002-0

[78] Ward, J.H. (1963) Hierarchical Grouping to Optimize an Object Function. Journal of American Statistical Association, 58, 236-244. https://doi.org/10.1080/01621459.1963.10500845 
[79] Wishart, D. (1969) Clus 1A User Mannual, Computer Laboratory. University of St. Andrews, St. Andrews.

[80] Everitt, B. (1974) Cluster Analysis. Heinemann Educational Books Ltd., London.

[81] Beheiry, S. (1969) Geomorphology of Central East Jordan. Bulletin de la Societe de Geographic d Egypt, 41, 5-22.

[82] Hassan, M.A. and Klein, M. (2002) Fluvial Adjustment of the Lower Jordan River to a Drop in the Dead Sea Level. Geomorphology, 45, 21-33.

[83] Merriam, D.F. (1966) Colloquim on Classification Procedures. Computer Contribution 7, State Geological Survey. The University of Kansas, Lawrence. 


\section{Appendix}

Table A1. Morphometric characteristics of the 76 sub-basins of W. Mujib-Wala watershed

\begin{tabular}{|c|c|c|c|c|c|c|c|c|c|c|c|c|c|c|c|c|c|c|c|c|c|c|}
\hline $\begin{array}{c}\text { Sub-basin } \\
\text { no. }\end{array}$ & $\mathrm{N}_{\mathrm{u}}$ & $\mathrm{L}_{\mathrm{u}}$ & $\mathrm{L}_{s \mathrm{~m}}$ & $\mathbf{R}_{\mathrm{bm}}$ & RHO & $\mathrm{L}_{\mathrm{o}}$ & A & $\mathrm{p}$ & $\mathbf{R}_{\mathrm{f}}$ & $D_{t}$ & $\mathbf{R}_{c}$ & $\mathbf{R}_{\mathrm{e}}$ & $\mathrm{F}_{s}$ & $\mathrm{D}_{\mathrm{d}}$ & $\mathrm{B}_{s}$ & C & $\mathrm{C}_{\mathrm{c}}$ & $B_{h}$ & $R_{r}$ & $\mathbf{R}_{\mathrm{n}}$ & $D_{\text {is }}$ & $\mathbf{M}_{\mathrm{rn}}$ \\
\hline 1. & 60 & 67.0 & 1.1 & 3.6 & 0.28 & 0.62 & 54.1 & 47.7 & 0.31 & 1.37 & 0.30 & 0.63 & 1.11 & 1.2 & 3.2 & 0.81 & 3.7 & 281 & 21.4 & 0.35 & 0.28 & 38.2 \\
\hline 2. & 112 & 128.9 & 1.2 & 4.5 & 0.22 & 0.63 & 103.0 & 93.1 & 0.22 & 1.36 & 0.15 & 0.53 & 1.09 & 1.3 & 4.5 & 0.80 & 5.2 & 278 & 12.9 & 0.35 & 0.29 & 27.4 \\
\hline 3. & 93 & 123.8 & 1.3 & 4.3 & 0.24 & 0.71 & 86.6 & 60.8 & 0.50 & 1.53 & 0.29 & 0.80 & 1.07 & 1.4 & 2.0 & 0.70 & 3.7 & 242 & 18.4 & 0.35 & 0.25 & 26.0 \\
\hline 4. & 108 & 131.1 & 1.2 & 4.6 & 0.22 & 0.66 & 98.8 & 90.9 & 0.19 & 1.45 & 0.15 & 0.49 & 1.09 & 1.3 & 5.4 & 0.75 & 5.2 & 277 & 12.0 & 0.37 & 0.29 & 27.9 \\
\hline 5. & 160 & 184.6 & 1.2 & 5.1 & 0.20 & 0.71 & 130.2 & 81.2 & 0.45 & 1.74 & 0.25 & 0.76 & 1.23 & 1.4 & 2.2 & 0.71 & 4.0 & 236 & 13.9 & 0.33 & 0.26 & 20.7 \\
\hline 6. & 35 & 30.3 & 0.9 & 3.1 & 0.33 & 0.77 & 19.8 & 24.8 & 0.37 & 2.72 & 0.40 & 0.69 & 1.77 & 1.5 & 2.7 & 0.65 & 3.1 & 117 & 16.0 & 0.18 & 0.15 & 26.3 \\
\hline 7. & 54 & 69.0 & 1.3 & 3.5 & 0.29 & 0.68 & 50.8 & 43.8 & 0.31 & 1.45 & 0.33 & 0.63 & 1.06 & 1.4 & 3.2 & 0.74 & 3.5 & 148 & 11.6 & 0.20 & 0.18 & 20.8 \\
\hline 8. & 78 & 86.3 & 1.1 & 4.0 & 0.26 & 0.75 & 57.6 & 45.5 & 0.30 & 2.03 & 0.35 & 0.62 & 1.35 & 1.5 & 3.3 & 0.67 & 3.4 & 228 & 16.5 & 0.34 & 0.26 & 30.0 \\
\hline 9. & 58 & 72.8 & 1.3 & 3.9 & 0.26 & 0.68 & 53.7 & 51.8 & 0.37 & 1.47 & 0.25 & 0.69 & 1.08 & 1.4 & 2.7 & 0.74 & 4.0 & 287 & 23.9 & 0.39 & 0.36 & 39.2 \\
\hline 10. & 28 & 31.9 & 1.1 & 2.7 & 0.38 & 0.89 & 18.0 & 22.7 & 0.33 & 2.75 & 0.44 & 0.64 & 1.56 & 1.8 & 3.1 & 0.56 & 3.0 & 243 & 32.7 & 0.43 & 0.25 & 57.3 \\
\hline 11. & 34 & 39.1 & 1.1 & 3.0 & 0.34 & 0.79 & 24.7 & 34.0 & 0.25 & 2.18 & 0.27 & 0.56 & 1.38 & 1.6 & 4.1 & 0.63 & 3.9 & 233 & 23.2 & 0.37 & 0.24 & 46.9 \\
\hline 12. & 238 & 265.1 & 1.1 & 5.8 & 0.17 & 0.72 & 185.0 & 135.6 & 0.30 & 1.84 & 0.13 & 0.62 & 1.29 & 1.4 & 3.3 & 0.70 & 5.6 & 273 & 11.0 & 0.39 & 0.28 & 20.1 \\
\hline 13. & 150 & 170.4 & 1.1 & 5.0 & 0.20 & 0.68 & 125.9 & 153.6 & 0.09 & 1.61 & 0.07 & 0.33 & 1.19 & 1.4 & 11.6 & 0.74 & 7.7 & 324 & 8.5 & 0.44 & 0.33 & 28.9 \\
\hline 14. & 51 & 51.7 & 1.0 & 3.6 & 0.28 & 0.70 & 37.0 & 44.0 & 0.43 & 1.93 & 0.24 & 0.74 & 1.38 & 1.4 & 2.3 & 0.72 & 4.1 & 355 & 38.3 & 0.50 & 0.45 & 58.3 \\
\hline 15. & 70 & 64.8 & 0.9 & 4.3 & 0.24 & 0.67 & 48.6 & 55.6 & 0.18 & 1.92 & 0.20 & 0.48 & 1.44 & 1.3 & 5.6 & 0.75 & 4.5 & 203 & 12.3 & 0.27 & 0.25 & 29.1 \\
\hline 16. & 38 & 40.2 & 1.1 & 3.1 & 0.33 & 0.69 & 29.3 & 28.2 & 0.81 & 1.78 & 0.46 & 101 & 1.30 & 1.4 & 1.2 & 0.73 & 2.9 & 458 & 76.1 & 0.63 & 0.57 & 84.6 \\
\hline 17. & 99 & 112.2 & 1.1 & 4.4 & 0.23 & 0.64 & 87.2 & 81.6 & 0.25 & 1.46 & 0.16 & 0.56 & 1.14 & 1.3 & 4.1 & 0.78 & 4.9 & 338 & 18.0 & 0.44 & 0.41 & 36.2 \\
\hline 18. & 34 & 37.4 & 1.1 & 3.2 & 0.32 & 0.65 & 29.0 & 37.0 & 0.25 & 1.51 & 0.27 & 0.57 & 1.17 & 1.3 & 3.9 & 0.78 & 3.9 & 333 & 31.2 & 0.43 & 0.43 & 61.9 \\
\hline 19. & 139 & 175.9 & 1.3 & 4.8 & 0.21 & 0.74 & 118.5 & 102.1 & 0.19 & 1.74 & 0.14 & 0.49 & 1.17 & 1.5 & 5.3 & 0.67 & 5.3 & 230 & 9.2 & 0.34 & 0.25 & 21.1 \\
\hline 20. & 99 & 129.9 & 1.3 & 4.4 & 0.23 & 0.72 & 89.7 & 80.2 & 0.31 & 1.60 & 0.18 & 0.63 & 1.10 & 1.4 & 3.2 & 0.69 & 4.8 & 207 & 12.2 & 0.30 & 0.24 & 21.9 \\
\hline 21. & 34 & 29.8 & 0.9 & 3.1 & 0.34 & 0.70 & 21.3 & 35.7 & 0.38 & 2.22 & 0.21 & 0.70 & 1.59 & 1.4 & 2.6 & 0.72 & 4.4 & 96 & 12.8 & 0.13 & 0.12 & 20.8 \\
\hline 22. & 27 & 24.2 & 0.9 & 3.0 & 0.35 & 0.64 & 18.8 & 22.8 & 0.37 & 1.84 & 0.46 & 0.69 & 1.43 & 1.3 & 2.7 & 0.78 & 3.0 & 135 & 18.9 & 0.17 & 0.17 & 31.1 \\
\hline 23. & 17 & 14.4 & 0.8 & 2.2 & 0.50 & 0.59 & 12.1 & 17.6 & 0.41 & 1.67 & 0.49 & 0.72 & 1.40 & 1.2 & 2.4 & 0.84 & 2.9 & 133 & 24.5 & 0.16 & 0.17 & 38.2 \\
\hline 24. & 55 & 60.0 & 1.1 & 3.7 & 0.27 & 0.69 & 43.8 & 43.9 & 0.50 & 1.72 & 0.29 & 0.79 & 1.26 & 1.4 & 2.0 & 0.73 & 3.7 & 266 & 28.3 & 0.36 & 0.32 & 40.2 \\
\hline 25. & 33 & 34.1 & 1.0 & 2.9 & 0.35 & 0.74 & 22.9 & 25.3 & 0.56 & 2.15 & 0.45 & 0.85 & 1.74 & 1.5 & 1.8 & 0.67 & 3.0 & 158 & 24.8 & 0.24 & 0.16 & 33.0 \\
\hline 26. & 52 & 53.1 & 1.0 & 3.7 & 0.27 & 0.71 & 37.6 & 49.1 & 0.25 & 1.95 & 0.20 & 0.56 & 138 & 1.4 & 4.1 & 0.71 & 4.5 & 194 & 15.7 & 0.27 & 0.20 & 31.6 \\
\hline 27. & 103 & 112.0 & 1.1 & 4.5 & 0.22 & 0.66 & 84.9 & 65.8 & 0.46 & 1.60 & 0.25 & 0.76 & 1.21 & 1.3 & 2.2 & 0.76 & 4.0 & 394 & 29.0 & 0.52 & 0.45 & 42.8 \\
\hline 28. & 137 & 157.4 & 1.1 & 4.8 & 0.21 & 0.68 & 115.8 & 112.7 & 0.20 & 1.61 & 0.11 & 0.50 & 1.18 & 1.4 & 5.0 & 0.74 & 5.9 & 880 & 36.4 & 1.20 & 0.83 & 81.8 \\
\hline 29. & 88 & 103.9 & 1.2 & 4.2 & 0.24 & 0.74 & 70.1 & 68.2 & 0.30 & 1.86 & 0.19 & 0.62 & 1.25 & 1.5 & 3.3 & 0.67 & 4.6 & 222 & 14.6 & 0.33 & 0.23 & 26.5 \\
\hline 30. & 69 & 72.2 & 1.0 & 3.8 & 0.27 & 0.65 & 55.9 & 54.0 & 0.25 & 1.59 & 0.24 & 0.56 & 1.23 & 1.3 & 4.0 & 0.77 & 4.1 & 644 & 43.1 & 0.83 & 0.66 & 86.1 \\
\hline 31. & 30 & 33.3 & 1.1 & 3.0 & 0.35 & 0.65 & 25.7 & 33.2 & 0.38 & 1.52 & 0.29 & 0.69 & 1.17 & 1.3 & 2.6 & 0.77 & 3.7 & 168 & 20.4 & 0.22 & 0.19 & 33.2 \\
\hline 32. & 36 & 43.2 & 1.2 & 3.2 & 0.32 & 0.79 & 27.2 & 32.5 & 0.55 & 2.11 & 0.32 & 0.84 & 1.33 & 1.6 & 1.8 & 0.63 & 3.5 & 134 & 19.1 & 0.21 & 0.15 & 25.7 \\
\hline 33. & 35 & 43.2 & 1.2 & 11.3 & 0.09 & 0.67 & 32.1 & 30.2 & 0.43 & 1.47 & 0.44 & 0.74 & 1.09 & 1.3 & 2.3 & 0.74 & 3.0 & 195 & 22.6 & 0.26 & 0.22 & 34.4 \\
\hline 34. & 46 & 54.7 & 1.2 & 3.4 & 0.30 & 0.72 & 38.0 & 41.1 & 0.32 & 1.74 & 0.28 & 0.64 & 1.21 & 1.4 & 3.1 & 0.69 & 3.8 & 158 & 14.6 & 0.23 & 0.18 & 25.6 \\
\hline 35. & 28 & 31.2 & 1.1 & 2.7 & 0.38 & 0.77 & 20.3 & 18.4 & 0.38 & 2.12 & 0.75 & 0.70 & 1.38 & 1.5 & 2.6 & 0.65 & 2.3 & 181 & 24.9 & 0.28 & 0.19 & 40.2 \\
\hline 36. & 64 & 84.2 & 1.3 & 4.0 & 0.25 & 0.71 & 59.5 & 55.6 & 0.25 & 1.52 & 0.24 & 0.56 & 1.08 & 1.4 & 4.1 & 0.71 & 4.1 & 479 & 30.8 & 0.68 & 0.44 & 62.1 \\
\hline 37. & 35 & 32.6 & 0.9 & 3.0 & 0.34 & 0.72 & 22.6 & 33.0 & 0.32 & 2.23 & 0.26 & 0.64 & 1.55 & 1.4 & 3.1 & 0.69 & 3.9 & 167 & 19.9 & 0.24 & 0.17 & 35.1 \\
\hline 38. & 44 & 43.4 & 1.0 & 3.4 & 0.30 & 0.71 & 30.4 & 37.6 & 0.43 & 2.06 & 0.27 & 0.74 & 1.45 & 1.4 & 2.3 & 0.70 & 3.9 & 98 & 11.7 & 0.14 & 0.11 & 17.8 \\
\hline
\end{tabular}




\section{Continued}

\begin{tabular}{|c|c|c|c|c|c|c|c|c|c|c|c|c|c|c|c|c|c|c|c|c|c|}
\hline 39. & 28 & 33.3 & 1.2 & 2.8 & 0.36 & 0.66 & 25.1 & 35.6 & 0.22 & 1.48 & 0.25 & 0.53 & 1.12 & 1.3 & 4.6 & 0.75 & 4.0 & 162 & 15.1 & $\begin{array}{lll}0.22 & 0.17\end{array}$ & 32.3 \\
\hline 40. & 76 & 96.6 & 1.3 & 3.9 & 0.26 & 0.72 & 66.8 & 66.2 & 0.27 & 1.64 & 0.19 & 0.58 & 1.14 & 1.4 & 3.8 & 0.69 & 4.6 & 249 & 15.7 & 0.360 .26 & 30.5 \\
\hline 41. & 68 & 79.2 & 1.2 & 3.8 & 0.26 & 0.75 & 52.7 & 58.6 & 0.33 & 1.94 & 0.19 & 0.65 & 1.29 & 1.5 & 3.0 & 0.67 & 4.6 & 165 & 13.1 & $\begin{array}{lll}0.25 & 0.17\end{array}$ & 22.7 \\
\hline 42. & 45 & 44.9 & 1.0 & 3.4 & 0.30 & 0.70 & 32.0 & 39.2 & 0.38 & 1.97 & 0.26 & 0.69 & 1.40 & 1.4 & 2.7 & 0.71 & 3.9 & 135 & 14.6 & 0.190 .15 & 23.8 \\
\hline 43. & 30 & 30.2 & 1.0 & 2.7 & 0.39 & 0.67 & 22.6 & 27.5 & 0.44 & 1.78 & 0.38 & 0.75 & 1.33 & 1.3 & 2.3 & 0.75 & 3.3 & 110 & 15.3 & $0.15 \quad 0.12$ & 23.1 \\
\hline 44. & 85 & 100.5 & 1.2 & 4.0 & 0.25 & 0.67 & 75.2 & 73.4 & 0.68 & 1.51 & 0.18 & 0.93 & 1.13 & 1.3 & 1.5 & 0.75 & 4.8 & 124 & 11.8 & $\begin{array}{lll}0.17 & 0.14\end{array}$ & 14.3 \\
\hline 45. & 44 & 53.3 & 1.2 & 3.5 & 0.30 & 0.69 & 38.6 & 40.1 & 0.20 & 1.57 & 0.30 & 0.51 & 1.14 & 1.4 & 4.9 & 0.73 & 3.6 & 268 & 19.4 & $\begin{array}{lll}0.37 & 0.27\end{array}$ & 43.1 \\
\hline 46. & 51 & 65.3 & 1.3 & 4.4 & 0.23 & 0.64 & 50.6 & 52.9 & 0.23 & 1.30 & 0.23 & 0.54 & 1.01 & 1.3 & 4.4 & 0.78 & 4.2 & 318 & 21.3 & 0.410 .30 & 44.7 \\
\hline 47. & 30 & 29.4 & 1.0 & 3.0 & 0.35 & 0.80 & 18.4 & 28.2 & 0.69 & 2.61 & 0.29 & 0.94 & 1.63 & 1.6 & 1.4 & 0.63 & 3.7 & 93 & 18.0 & $\begin{array}{ll}0.15 & 0.11\end{array}$ & 21.7 \\
\hline 48. & 70 & 74.2 & 1.1 & 4.0 & 0.25 & 0.67 & 55.7 & 50.5 & 0.31 & 1.67 & 0.27 & 0.63 & 1.26 & 1.3 & 3.2 & 0.75 & 3.8 & 302 & 22.6 & 0.400 .26 & 40.5 \\
\hline 49. & 75 & 86.7 & 1.2 & 3.8 & 0.27 & 0.68 & 63.5 & 49.0 & 0.31 & 1.61 & 0.33 & 0.62 & 1.18 & 1.4 & 3.3 & 0.73 & 3.5 & 394 & 27.3 & $\begin{array}{lll}0.54 & 0.31\end{array}$ & 49.4 \\
\hline 50. & 45 & 58.2 & 1.3 & 3.4 & 0.30 & 0.67 & 43.6 & 46.1 & 0.38 & 1.38 & 0.26 & 0.70 & 1.03 & 1.3 & 2.6 & 0.75 & 3.9 & 198 & 18.6 & 0.260 .20 & 30.0 \\
\hline 51. & 37 & 50.2 & 1.4 & 3.1 & 0.33 & 0.73 & 34.5 & 40.0 & 0.22 & 1.57 & 0.27 & 0.53 & 1.07 & 1.5 & 4.5 & 0.69 & 3.8 & 161 & 12.9 & $0.23 \quad 0.17$ & 27.4 \\
\hline 52. & 85 & 91.0 & 1.1 & 4.0 & 0.25 & 0.71 & 64.0 & 59.0 & 0.31 & 1.89 & 0.23 & 0.63 & 1.33 & 1.4 & 3.2 & 0.70 & 4.2 & 176 & 12.3 & 0.250 .18 & 22.0 \\
\hline 53. & 102 & 107.7 & 1.1 & 4.3 & 0.24 & 0.71 & 75.9 & 81.5 & 0.28 & 1.90 & 0.14 & 0.60 & 1.34 & 1.4 & 3.6 & 0.71 & 5.3 & 168 & 10.2 & $\begin{array}{lll}0.24 & 0.18\end{array}$ & 19.3 \\
\hline 54. & 43 & 43.6 & 1.0 & 3.4 & 0.30 & 0.78 & 27.9 & 22.1 & 0.75 & 2.40 & 0.72 & 0.97 & 1.54 & 1.6 & 1.3 & 0.64 & 2.4 & 156 & 25.5 & 0.240 .16 & 29.5 \\
\hline 55. & 123 & 131.4 & 1.1 & 4.6 & 0.22 & 0.71 & 92.9 & 108.1 & 0.14 & 1.87 & 0.10 & 0.42 & 1.32 & 1.4 & 7.0 & 0.71 & 6.3 & 262 & 10.2 & $\begin{array}{lll}0.37 & 0.24\end{array}$ & 27.2 \\
\hline 56. & 30 & 32.1 & 1.1 & 3.3 & 0.32 & 0.70 & 23.0 & 24.4 & 0.24 & 1.82 & 0.49 & 0.55 & 1.30 & 1.4 & 4.2 & 0.72 & 2.9 & 142 & 14.4 & 0.200 .16 & 29.6 \\
\hline 57. & 50 & 55.8 & 1.1 & 3.6 & 0.28 & 0.66 & 42.1 & 47.3 & 0.36 & 1.58 & 0.24 & 0.68 & 1.19 & 1.3 & 2.8 & 0.75 & 4.1 & 180 & 16.7 & $0.24 \quad 0.19$ & 27.7 \\
\hline 58. & 152 & 164.3 & 1.1 & 5.0 & 0.20 & 0.69 & 119.3 & 89.1 & 0.22 & 1.75 & 0.19 & 0.53 & 1.27 & 1.4 & 4.6 & 0.73 & 4.6 & 396 & 16.9 & $\begin{array}{lll}0.55 & 0.31\end{array}$ & 36.2 \\
\hline 59. & 41 & 47.2 & 1.2 & 3.3 & 0.31 & 0.73 & 32.4 & 39.4 & 0.26 & 1.84 & 0.26 & 0.58 & 1.27 & 1.5 & 3.8 & 0.69 & 3.9 & 121 & 10.9 & 0.180 .13 & 21.3 \\
\hline 60. & 49 & 58.8 & 1.2 & 3.3 & 0.31 & 0.80 & 36.8 & 41.2 & 0.27 & 2.12 & 0.27 & 0.59 & 1.33 & 1.6 & 3.7 & 0.63 & 3.8 & 180 & 15.5 & 0.290 .18 & 29.7 \\
\hline 61. & 34 & 177.7 & 5.2 & 5.1 & 0.20 & 0.77 & 116.0 & 84.4 & 0.21 & 0.45 & 0.20 & 0.52 & 0.29 & 1.5 & 4.7 & 0.65 & 4.4 & 239 & 10.2 & $\begin{array}{lll}0.37 & 0.23\end{array}$ & 22.2 \\
\hline 62. & 50 & 57.4 & 1.1 & 3.6 & 0.28 & 0.73 & 39.3 & 39.4 & 0.40 & 1.86 & 0.32 & 0.71 & 1.27 & 1.5 & 2.5 & 0.69 & 3.5 & 105 & 10.6 & $\begin{array}{ll}0.15 & 0.11\end{array}$ & 16.8 \\
\hline 63. & 40 & 41.4 & 1.0 & 3.2 & 0.32 & 0.75 & 27.7 & 37.4 & 0.31 & 2.16 & 0.25 & 0.63 & 1.44 & 1.5 & 3.2 & 0.67 & 4.0 & 101 & 10.8 & $\begin{array}{ll}0.15 & 0.11\end{array}$ & 19.2 \\
\hline 64. & 75 & 83.5 & 1.1 & 3.9 & 0.26 & 0.74 & 56.3 & 47.9 & 0.34 & 1.98 & 0.31 & 0.66 & 1.33 & 1.5 & 3.0 & 0.67 & 3.6 & 204 & 15.8 & $\begin{array}{lll}0.30 & 0.21\end{array}$ & 27.2 \\
\hline 65. & 30 & 26.7 & 0.9 & 2.8 & 0.37 & 0.65 & 20.5 & 23.5 & 0.26 & 1.90 & 0.47 & 0.58 & 1.46 & 1.3 & 3.8 & 0.77 & 2.9 & 167 & 18.9 & 0.220 .16 & 36.9 \\
\hline 66. & 39 & 40.7 & 1.0 & 3.2 & 0.32 & 0.74 & 27.4 & 33.7 & 0.34 & 2.12 & 0.30 & 0.66 & 1.42 & 1.5 & 2.9 & 0.67 & 3.6 & 113 & 12.6 & $\begin{array}{lll}0.17 & 0.12\end{array}$ & 21.6 \\
\hline 67. & 70 & 77.1 & 1.1 & 3.8 & 0.27 & 0.73 & 52.7 & 58.5 & 0.47 & 1.94 & 0.19 & 0.77 & 1.33 & 1.5 & 2.1 & 0.68 & 4.5 & 176 & 16.6 & 0.260 .19 & 24.2 \\
\hline 68. & 62 & 73.3 & 1.2 & 4.0 & 0.26 & 0.69 & 52.9 & 58.1 & 0.45 & 1.62 & 0.20 & 0.76 & 1.17 & 1.4 & 2.2 & 0.72 & 4.5 & 171 & 15.8 & $0.24 \quad 0.18$ & 23.5 \\
\hline 69. & 51 & 65.0 & 1.3 & 3.7 & 0.28 & 0.78 & 41.6 & 41.6 & 0.27 & 1.92 & 0.30 & 0.58 & 1.23 & 1.6 & 3.7 & 0.64 & 3.6 & 218 & 17.5 & $\begin{array}{lll}0.34 & 0.21\end{array}$ & 33.8 \\
\hline 70. & 34 & 42.4 & 1.2 & 3.0 & 0.34 & 0.69 & 30.6 & 37.2 & 0.23 & 1.54 & 0.28 & 0.55 & 1.11 & 1.4 & 4.3 & 0.72 & 3.8 & 95 & 8.3 & 0.130 .10 & 17.2 \\
\hline 71. & 211 & 239.0 & 1.1 & 5.8 & 0.17 & 0.71 & 167.8 & 128.1 & 0.33 & 1.79 & 0.13 & 0.65 & 1.26 & 1.4 & 3.0 & 0.70 & 5.6 & 165 & 7.3 & $\begin{array}{ll}0.23 & 0.17\end{array}$ & 12.7 \\
\hline 72. & 23 & 23.3 & 1.0 & 2.7 & 0.39 & 0.75 & 15.5 & 19.3 & 0.31 & 2.24 & 0.52 & 0.63 & 1.49 & 1.5 & 3.2 & 0.66 & 2.8 & 98 & 13.9 & 0.150 .10 & 24.9 \\
\hline 73. & 112 & 142.6 & 1.3 & 4.6 & 0.22 & 0.76 & 93.7 & 76.2 & 0.28 & 1.82 & 0.20 & 0.60 & 1.20 & 1.5 & 3.5 & 0.66 & 4.4 & 150 & 8.2 & $0.23 \quad 0.15$ & 15.5 \\
\hline 74. & 45 & 45.0 & 1.0 & 3.3 & 0.31 & 0.73 & 30.9 & 40.5 & 0.24 & 2.12 & 0.24 & 0.56 & 1.46 & 1.5 & 4.1 & 0.69 & 4.1 & 143 & 12.7 & 0.210 .14 & 25.7 \\
\hline 75. & 59 & 69.2 & 1.2 & 3.9 & 0.26 & 0.73 & 47.3 & 53.7 & 0.23 & 1.82 & 0.21 & 0.54 & 1.25 & 1.5 & 4.4 & 0.68 & 4.4 & 125 & 8.7 & $\begin{array}{ll}0.18 & 0.12\end{array}$ & 18.2 \\
\hline 76. & 90 & 95.2 & 1.1 & 4.2 & 0.24 & 0.70 & 68.2 & 61.6 & 0.33 & 1.84 & 0.23 & 0.65 & 1.32 & 1.4 & 3.1 & 0.72 & 4.2 & 139 & 9.6 & $\begin{array}{lll}0.19 & 0.13\end{array}$ & 16.8 \\
\hline
\end{tabular}


Submit or recommend next manuscript to SCIRP and we will provide best service for you:

Accepting pre-submission inquiries through Email, Facebook, LinkedIn, Twitter, etc. A wide selection of journals (inclusive of 9 subjects, more than 200 journals)

Providing 24-hour high-quality service

User-friendly online submission system

Fair and swift peer-review system

Efficient typesetting and proofreading procedure

Display of the result of downloads and visits, as well as the number of cited articles Maximum dissemination of your research work

Submit your manuscript at: http://papersubmission.scirp.org/

Or contact ojmh@scirp.org 